\title{
The geology of the northern part of the apliki Cyprus-type ore deposit
}

\author{
Antivachis D.N. \\ National and Kapodistrian University of Athens, School of Science, Faculty of \\ Geology and Geoenvironment, Department of Economic Geology and \\ Geochemistry, Panepistimioupoli, Zographou, Athens 157 84, Greece. \\ antivachis@gmail.com
}

\begin{abstract}
The Apliki copper deposit, in the Troodos ophiolite complex of Cyprus, is part of the Skouriotissa mining district. Mining activity at Apliki has resulted in the production of 1,650,000 tons of copper ore. The mineralization is hosted within the sequence of Lower Pillow Lavas of the Troodos ophiolite complex in the western part of the Solea graben.

Plagioclase, pyroxenes (augite), magnetite and ilmenite, and rarely olivine are the main magmatic mineral components. The prevailing secondary minerals are celadonite, calcite, analcime and quartz which occur within amygdules or are dispersed within the rock matrix. The mineralized zone is bounded by two $\mathrm{N}-\mathrm{S}$ striking sub-parallel faults and is, therefore, controlled by local structures which allowed access to the hydrothermal fluids.

The basaltic Pillow Lavas at Apliki possess the same low-temperature regional scale alteration as the sequence of Lower Pillow Lavas of the Troodos ophiolite.

In the mineralized zone the following facies have been identified:

(a) A stockwork zone

(b) Veins of amorphous silica

(c) Veins of gypsum

(d) Oxidized vein of massive mineralization ("red zone")

(e) Oxidation zone

The Apliki deposit is associated with cupriferous massive sulphide which has been mined out. The Apliki mineralization, presently exposed in the examined area, is a typical example of stockwork type sulphide mineralization, with more intense presence in the lower levels of the northern wall, where the semi-massive and massive ore are preserved. The stockwork ore is hosted within brecciated chloritized lavas. Weak silicification is observed in the upper parts of the brecciated lavas. Red jasper is spatially associated with the mineralized lavas and occurs as veins or open-space fillings within the mineralized zone.

Pyrite, marcasite and chalcopyrite are the predominant ore minerals, whereas bornite, sphalerite, galena, and barite are accessories with quartz as the main gangue. Goethite, hematite, chalcocite, covellite, and $\mathrm{Fe}-, \mathrm{Cu}-, \mathrm{Pb}_{-}, \mathrm{Al}-$, and $\mathrm{Ca}-$ sulphates were formed in the supergene environment.
\end{abstract}

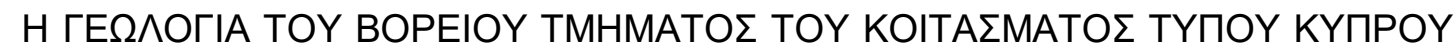
АП $\triangle I K I O Y$

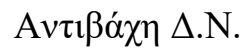


The sampling on the northern and southern wall, of the existing opencut, took place along a series of traverses based on a combined trench and rock-chip sampling method so to achieve the best representation of the samples taken. The spatial distribution of the major elements of the ore (Ag, As, $\mathrm{Au}, \mathrm{Cd}, \mathrm{Co}, \mathrm{Cu}, \mathrm{Fe}, \mathrm{Ni}, \mathrm{Pb}, \mathrm{S}, \mathrm{Se}, \mathrm{Sb}$ and $\mathrm{Zn})$ in the northern part of the opencut demonstrates an enrichment next to the western fault and at areas where the semimassive ore is present. Similar work was carried out on the southern part with much lower concentrations, a fact that reflects the limited occurrence of disseminated ore in that region. The spatial distribution of the major elements throughout the Apliki deposit has demonstrated that the western fault may be the one which is the controlling structure, while the eastern one is the boundary for a gradational passage into the Lower Pillow Lavas. Gold grade does not exceed $0.1 \mathrm{~g} / \mathrm{t}$, while copper grades ranges between 0.01 to $3.5 \mathrm{wt}$. \% and sulfur between 0.1 to 16 wt. \%.

Veins of gypsum, with a direction almost parallel to the western fault, and vein-like amorphous silica bodies both occur close to the western border within the mineralized zone. The "red zone", with an $\mathrm{N}-\mathrm{S}$ orientation, constitutes probably an oxidized vein of pyritechalcopyrite.

The mineralogical assemblage of Apliki oxidation zone (iron oxides and hydroxides, cuprite) reflects almost neutral $\mathrm{pH}$ conditions, a fact which is the result of insufficient amount of pyrite which produces low $\mathrm{pH}$ supergene solutions. The spatial distribution of copper and its content, which is almost the same with the respective one of primary sulphide mineralization, demonstrate the limited mobility of copper that instead of leaching and moving downwards is concentrated to the oxidation zone.

Key words: Cyprus-type deposits, Skouriotissa mines, Mineralogy, Geochemistry, Stockwork-type mineralization

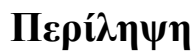

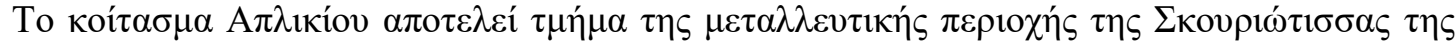

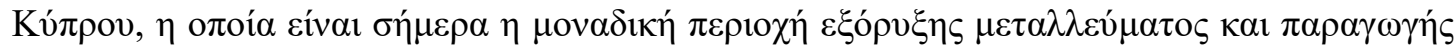

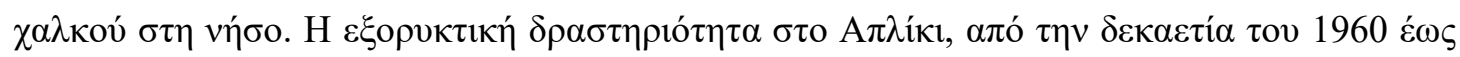

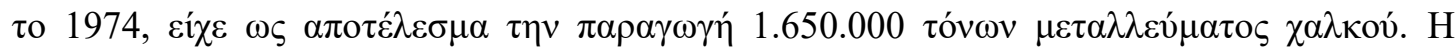

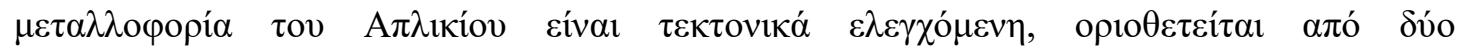

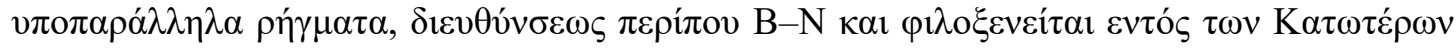

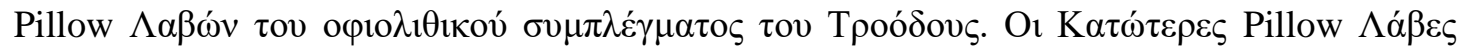

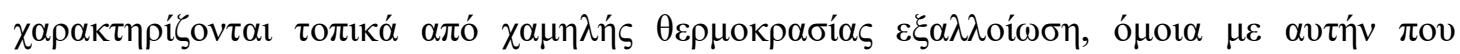

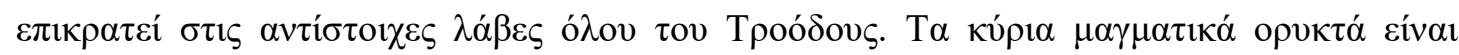

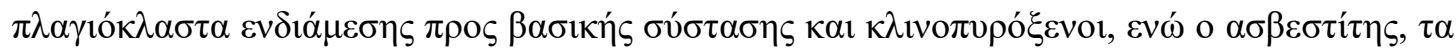

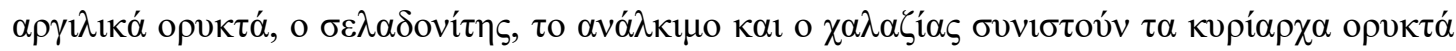

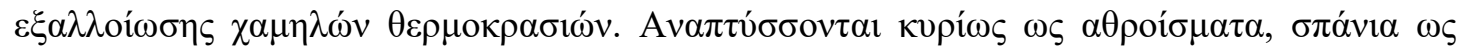

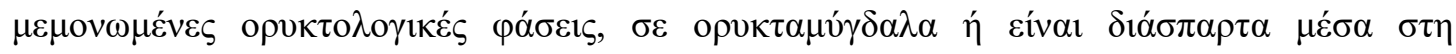
$\theta \varepsilon \mu \varepsilon \lambda \iota \dot{\delta} \eta \mu \alpha \dot{\zeta} \zeta \alpha$.

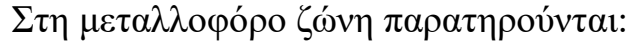
$(\alpha) \zeta \dot{v} \eta \eta$ stockwork

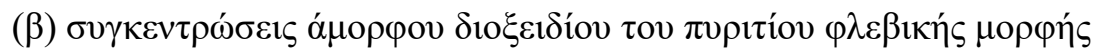

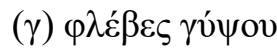

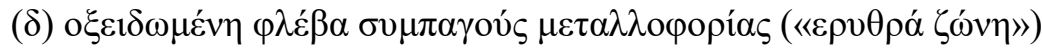

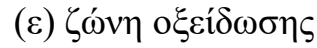




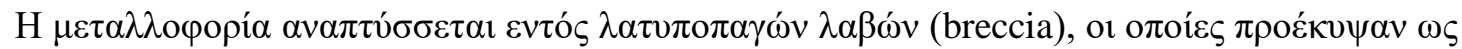

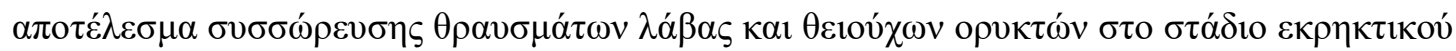

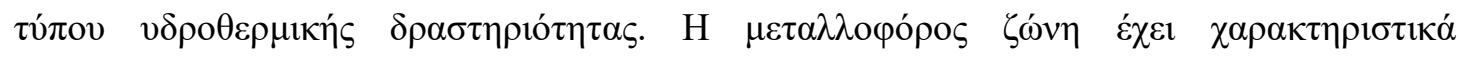

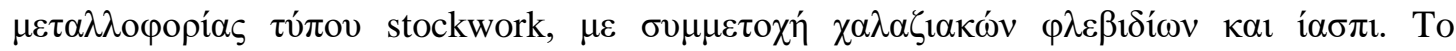

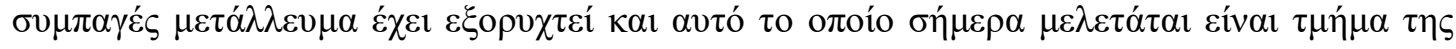

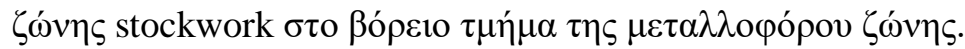

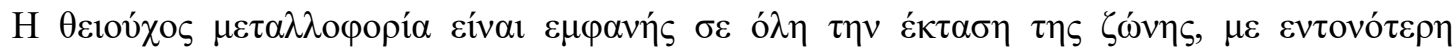

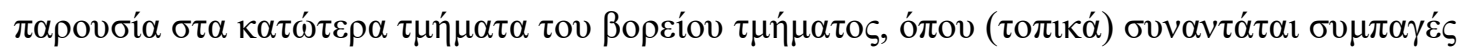

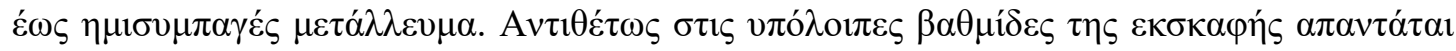

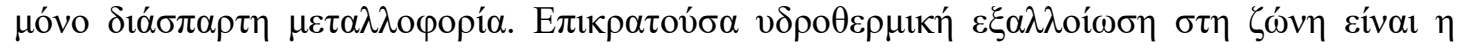

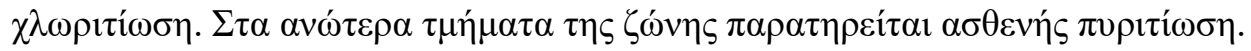

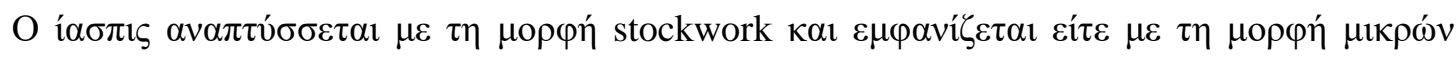

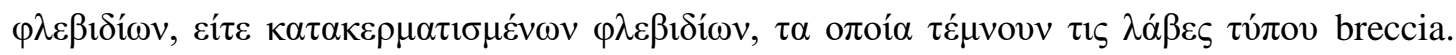

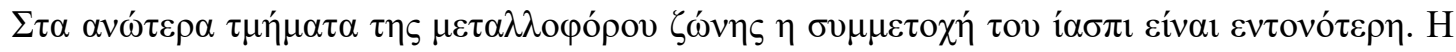

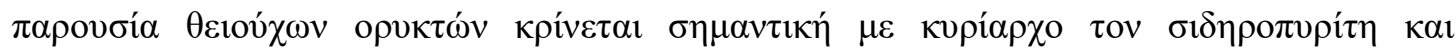

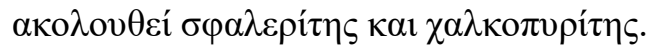

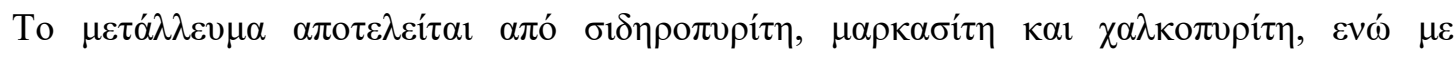

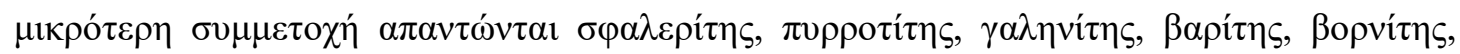

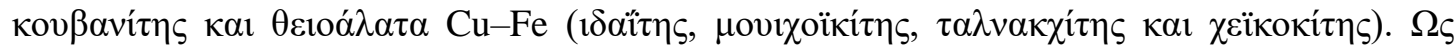

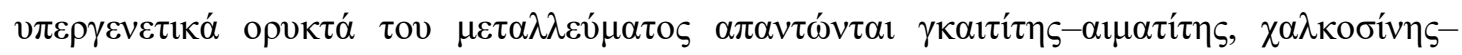

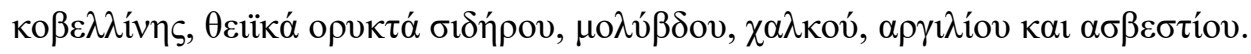

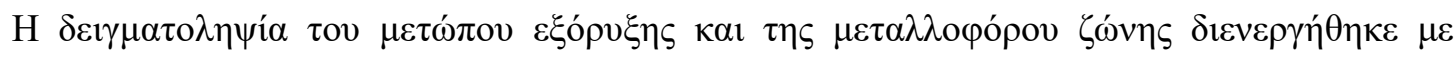

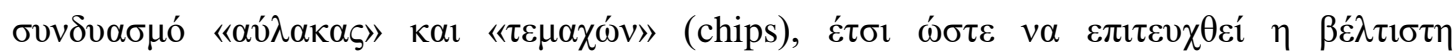

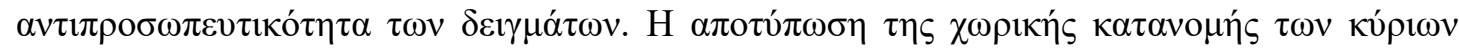

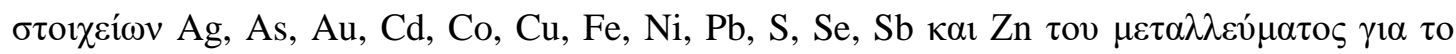

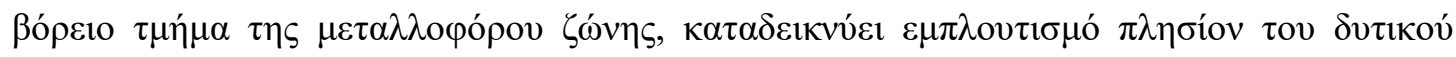

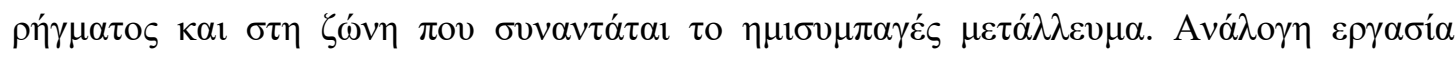

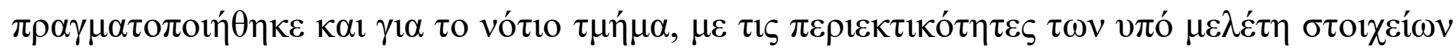

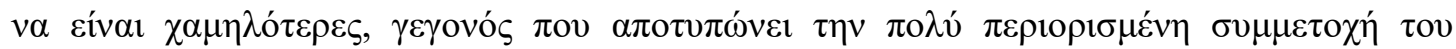

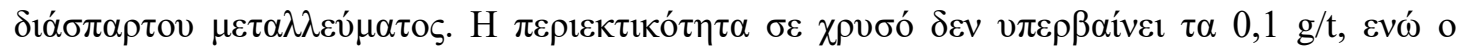

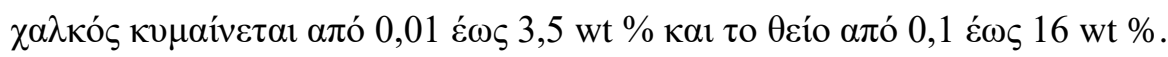

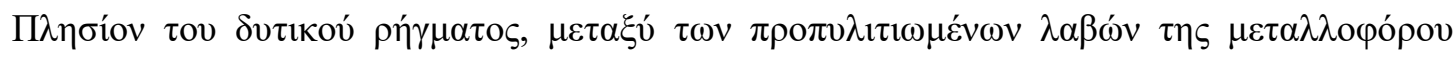

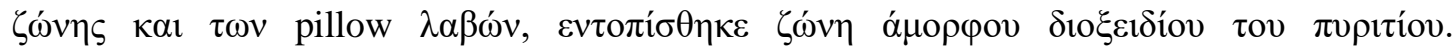

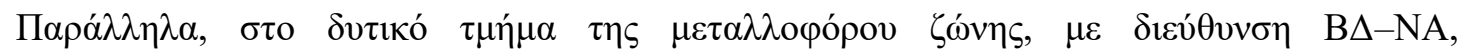

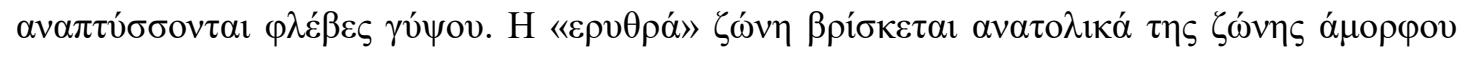

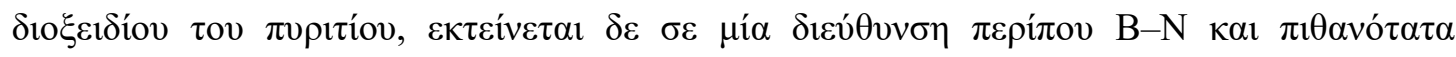

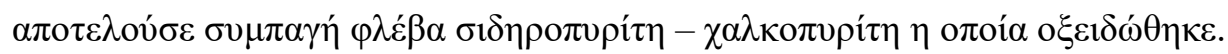

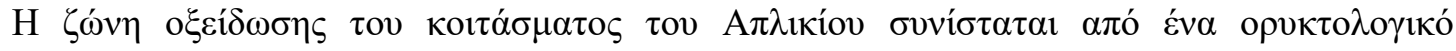

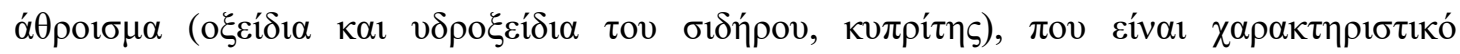

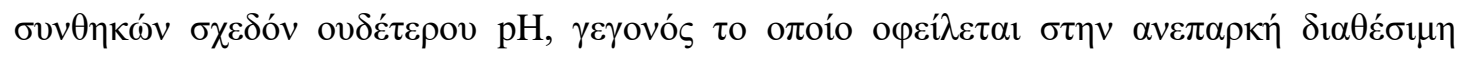

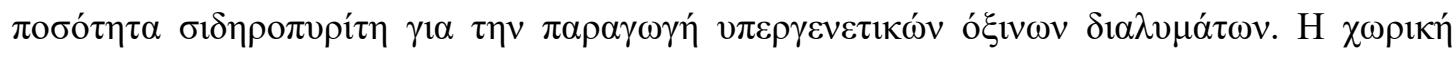

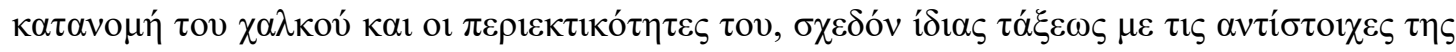

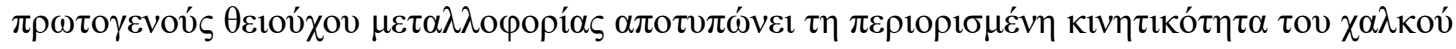

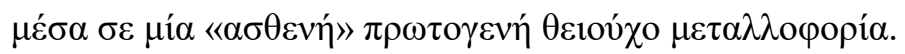

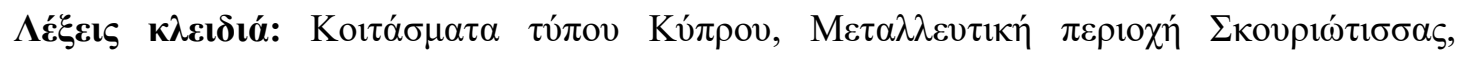

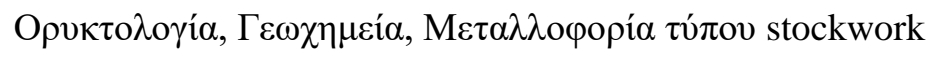




\section{Introduction}

Cyprus has become famous for copper extraction from sulphide deposits since ancient times (Hadjistavrinou and Constantinou, 1982) which was focused around 5 major mining districts (Skouriotissa, Limni, Kalavasos, Mitsero and Tamassos); the Apliki mine along with Skouriotissa, Mavrovouni, Phoukassa, Three Hills, Phoenix and East Lefka belong to the same mining district (Fig. 1.).

Cyprus sulphide deposits occur within the Pillow Lava Series of the Troodos ophiolite (Moores and Vine, 1971), which is generally considered to be a fragment of Mesozoic ocean floor, brought into position as a result of the collision between Eurasia and Africa (Gass and Masson-Smith, 1963). Cyprus-type massive sulphide deposits are usually structurally controlled by normal faults. Morphologically they are characterized by an upper zone of massive sulphide underlain by a stockwork of quartz, jasper and sulphide veins within the basaltic host Pillow Lavas. According to Adamides (1980) pyrite and chalcopyrite constitute the main ore minerals.

The Apliki mine (UTM 36S 485755E, $3881350 \mathrm{~N}$ ), constitutes a typical example of Cyprus-type Cu-bearing massive sulphide deposit (Constantinou, 1980), located 5 kilometers southwest of Skouriotissa mine (Fig. 1., 3.).Geographically it belongs to the Nicosia district and is situated very close to the ceasefire line, just south of the UNcontrolled buffer zone. The abandonment of Apliki mine in mid-1970s has left a deep pit, now hosting an acid pit lake fed by surface runoff, surrounded by the mineralized zone and the adjacent basaltic Pillow Lavas (Fig. 2.). The altitude at the bottom of the open pit is approximately 200 meters, and the top of the mineralized zone is 330 meters a.s.l. respectively. The width of the northern part of the opencut is estimated at 150 meters, while the southern one does not exceed 100 meters. The largest diameter of the lake is around 180 meters and the shortest 90 meters. The flora of the region is quite poor, with pine trees around the mine and the slopes. A smaller deposit (West Apliki) is also present and awaits exploitation (Fig. 3.).

Initial exploration at Apliki started in 1935 and the presence of sulphide mineralization was documented in 1937 (Bruce, 1947). Mining of the deposit started in the 1960s by Cyprus Mines Corporation (CMC) using opencut methods and ended in 1974 due to the Turkish invasion. Part of the oxidized ore was stockpiled separately and nowadays constitutes a valuable resource for hydrometallurgical exploitation by Hellenic Copper Mines Ltd (Adamides, 2010a). Up to the cessation of mining in 1974, approximately $1,650,000$ tons with $1.8 \% \mathrm{Cu}$ and $36 \% \mathrm{~S}$ were mined (Adamides, 1982). On the north side of the opencut a small amount of low-grade disseminated ore still remains, while the southern extensions merge into altered ground and are mainly covered under waste dumps (Adamides, 2010a).

It should be noted that there is an absence of scientific studies pertaining to the Apliki deposit with the notable exception of the unpublished studies of Hellenic Copper Ltd. and CMC which have been reviewed and reworked by Adamides (2003a; 2010a).

The aim of this paper is to study the geology of the northern part of the opencut of the Apliki mine including the chemistry of the ore and the hydrothermal alteration of basaltic Pillow Lava.

\section{Sampling and analytical techniques}

Pillow Lavas, ore and jasper samples were collected from the steep northern and southern slopes of the Apliki opencut along a series of traverses (Fig. 2.). 
Sampling in the northern wall was hindered by the presence of a landslide in the eastern part of the opencut, which covered approximately $15 \%$ of the sampling area. A number of benches presented sampling difficulties because of steep slopes and narrow width; however the problem was resolved by opening narrow paths, and the use of ladders for access. Nevertheless, the sampling is deemed adequate as it was supplemented by samples from the drill hole AM 9 provided by the Hellenic Copper Mines Ltd(Fig.2a.).

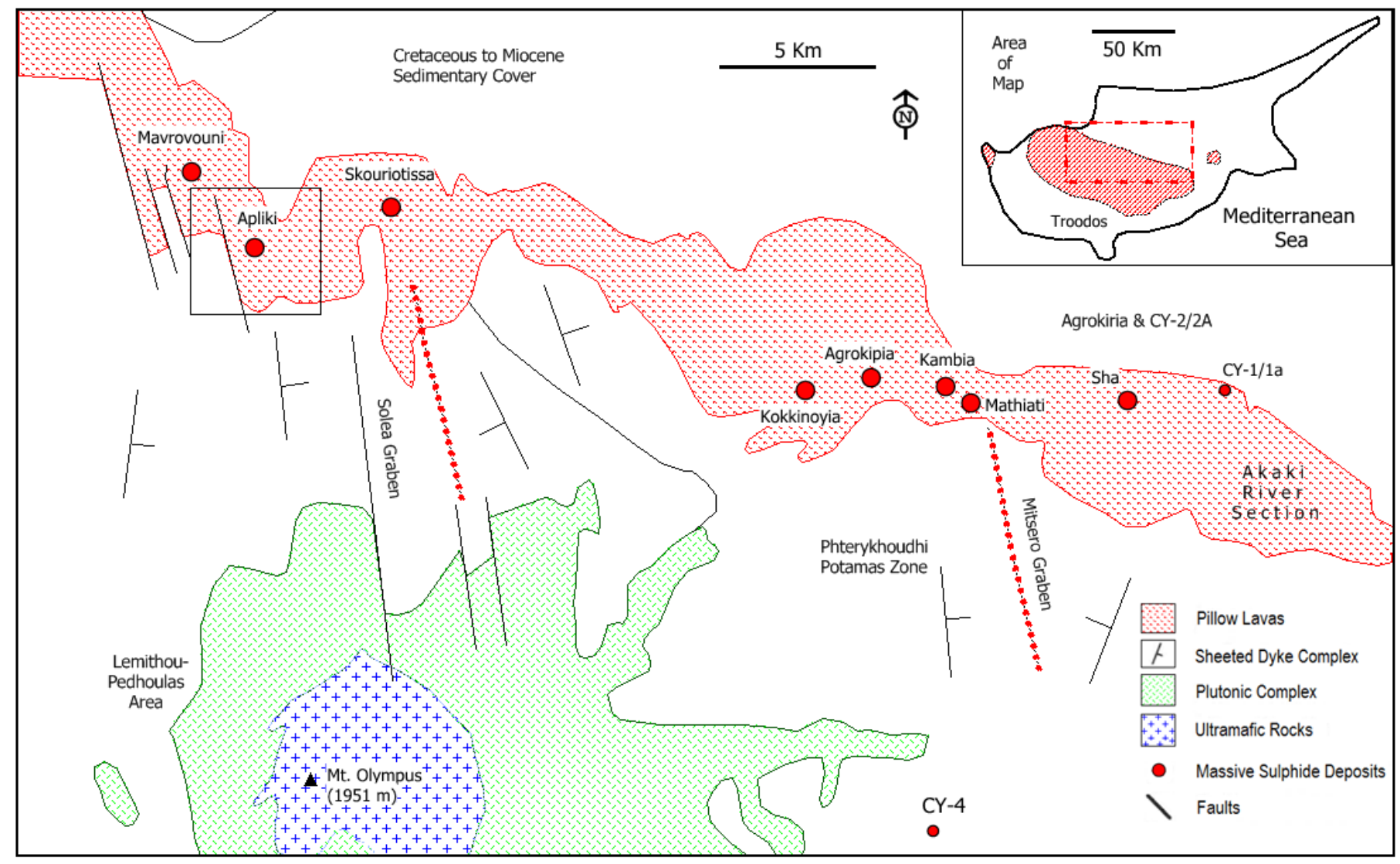

Fig. 1. Geological map of the Troodos ophiolite showing selected sulphide deposits. The Apliki deposit is outlined (Bickle and Teagle, 1992).

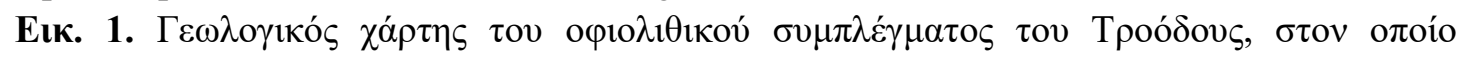

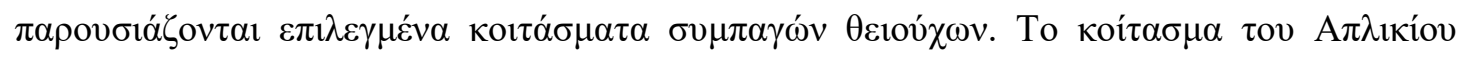

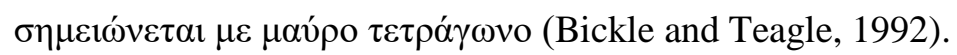

Sampling in the southern wall was limited with the focus being only on the mineralogical identification and the chemistry of the ore based on the very limited presence of disseminated ore, a fact which disallows safe and reliable conclusions.

The samples were pulverized and homogenized at the University of Athens, Department of Geology and Geoenvironment and analyzed by ALS, Ireland and
AcmeLabs, Canada by ICP-MS $\left(\mathrm{SiO}_{2}, \mathrm{Al}_{2} \mathrm{O}_{3}, \mathrm{CaO}\right.$, $\mathrm{Cr}_{2} \mathrm{O}_{3}, \mathrm{Fe}_{2} \mathrm{O}_{3}, \mathrm{~K}_{2} \mathrm{O}, \mathrm{MgO}, \mathrm{MnO}, \mathrm{Na}_{2} \mathrm{O}, \mathrm{P}_{2} \mathrm{O}_{5}, \mathrm{TiO}_{2}$ ) and ICP-AES, (Ag, As, Cd, Co, Cu, Hg, Fe, Ni, Pb, S, Se, $\mathrm{Sb}, \mathrm{Zr}, \mathrm{Zn}$ ) except for gold which was analyzed by AAS using a Perkin-Elmer 1100B device at the University of Athens. 

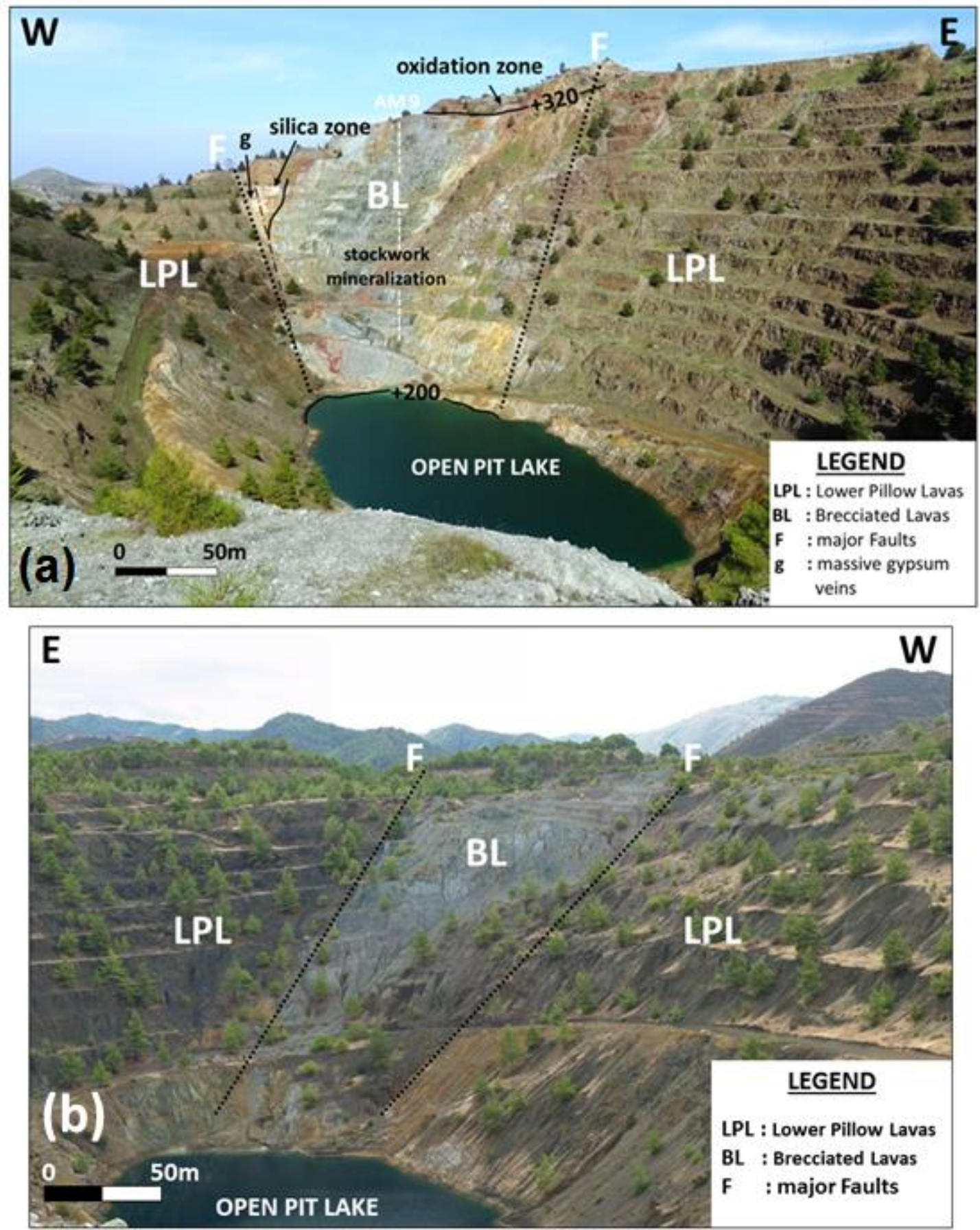

Fig. 2. General view of the northern (a) and southern (b) part of the Apliki abandoned mine.

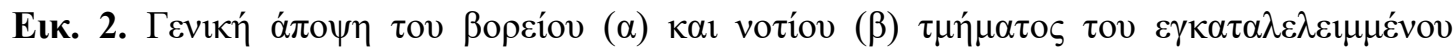
$\mu \varepsilon \tau \alpha \lambda \lambda \varepsilon i ́ o v ~ A \pi \lambda i ́ \kappa$. 
Petrographic work was performed at the University of Athens using a Leica combined transmitted and reflected microscope with digital camera attachment. The preliminary mineralogical identification of samples was performed by X-ray diffraction (XRD). For X-ray diffraction, a SIEMENS D-5005 diffractometer was used. All samples were scanned between $3-65^{\circ} 2 \theta$ angle with velocity of $1 \% \mathrm{~min}$, using the Ka radiation of a $\mathrm{Cu}$ X-ray tube, operated with a voltage of $40 \mathrm{kV}$ and a current of $40 \mathrm{~mA}$. The evaluation of the $\mathrm{X}$-ray diffractograms was performed with the EVA software, version 2.0. The mineralogy of primary and secondary minerals and backscattered imaging was performed using a Scanning Electron Microscope (SEM) JEOL JSM-5600 equipped with an EDS Oxford Link Isis 300 at the University of Athens. Microprobe analyses of silicate minerals were carried out at the Institute of
Mineralogy and Crystal Chemistry, at the University of Stuttgart, Germany, with the use of a CAMECA SX100 microprobe analyzer with integrated 5WDS spectometers, using acceleration voltage $15 \mathrm{kV}$ and beam current $10 \mathrm{nA}$.

\section{Geological Setting}

The Apliki deposit is located in the western part of the Solea graben (Varga and Moores, 1985) which can be construed as a special tectonic feature, of northnorthwest orientation, hosting some of the largest massive sulphide deposits in Cyprus (Adamides, 2010a). The Mavrovouni and Apliki deposits are in the western edge, while the Skouriotissa group deposits in the eastern edge of the graben. The geology of the area around the Apliki and its relationship to the other deposits of Solea Graben is shown in Fig. 1. and Fig. 3. respectively.
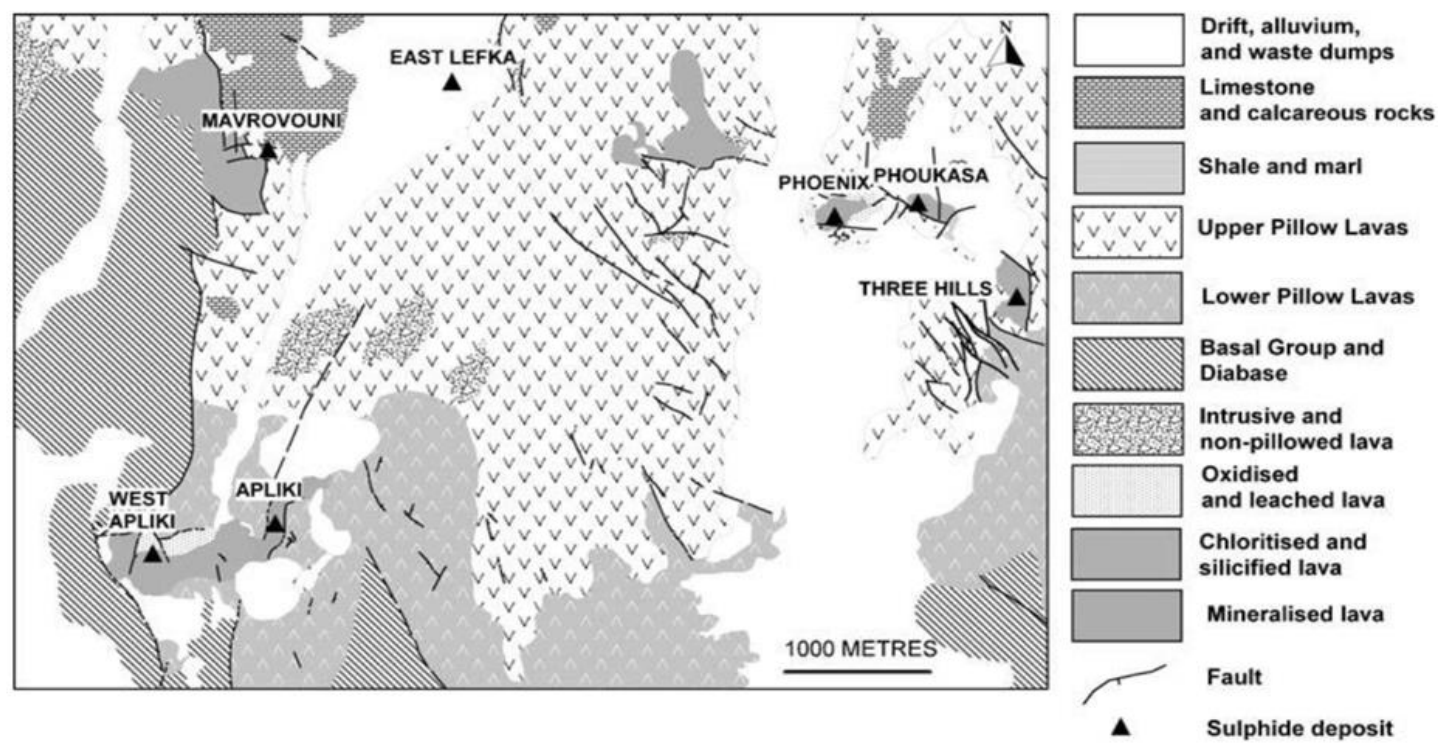

Fig. 3. Geological map of the Skouriotissa-Mavrovouni region (Adamides, 2010a).

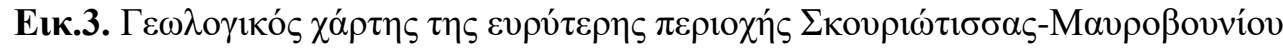
(Adamides, 2010a).

According to Varga and Moores (1985) the Solea graben is one of a series of interpreted tectonic features correlated with the evolution of the ophiolite at a spreading centre. Adamides (2010a) suggests that the Mavrovouni and Apliki deposits are localized by structures which are possible oceanic detachment faults. These sulphide deposits have been exploited both in ancient and modern times. 
Skouriotissa-Mavrovouni region includes three cupriferous massive sulphide deposits; Phoukasa or Skouriotissa, Phoenix and Three Hills. Additionally, the Apliki and West Apliki deposits belong in the same mining area. Detailed description of the deposits of the Skouriotissa group and their mineralogical characteristics are provided by Adamides (1984; 2010a), while their geological and tectonic features are shown in Fig. 3. The Phoukasa deposit is a classic example of Cyprus-type massive sulphide orebody with a lens of massive sulphide overlying a pipe of stockwork-type mineralization passing laterally into unaltered Upper Pillow Lavas. The Phoenix deposit is characterized by extensive disseminated mineralization in chlorite-bearing pillowed lavas which are partly covered by sedimentary rocks. Three Hills is a veintype deposit within Upper Pillow Lavas, surrounded by chloritic alteration and composed of pyrite and chalcopyrite with limited supergene enrichment. Mavrovouni is characterized by the presence of massive sulphide lens hosted within Pillow Lavas and enveloped by altered lavas with disseminated mineralization. The remaining part of the Apliki deposit, due to the fact that the cupriferous massive sulphide ore has been mined out, constitutes a typical example of stockwork type sulphide mineralization in chlorite-bearing and silicified lavas with an overlying oxidation zone.

\section{Results}

4.1 Petrology and host rock alteration of the Apliki Pillow Lavas

The dominant Apliki petrological unit is Lower Pillow Lavas which consist of ellipsoidal and/ or spheroidal forms of pillows. The Pillow Lavas are of brown to dark green colour and vary widely in size from a few centimeters to more than a meter in length (Fig. 2., 11A.). They are characterized by amygdaloidal texture with amygdules filled with zeolites and/or quartz. The interspace between the pillows is occupied by carbonates and/or clay minerals.

The controlling structure is northerly in orientation, whereas basaltic dykes that crosscut the Pillow Lavas exhibit a northwesterly strike, which is explained by the fact that the controlling fault is interpreted as a splay of the detachment fault to the west.

From the microscopic observation, the texture of the Apliki Pillow Lavas ranges from ophitic to sub-ophitic with variable content of volcanic glass. The matrix is characterized by microlitic texture, while in some samples flow structure is observed. Plagioclase, of intermediate to basic composition, pyroxenes (clino- and ortho-), iron and titanium oxides and rarely olivine are the dominant magmatic minerals.

The ternary classification diagram $\mathrm{Ab}-$ An-Or for feldspars (Fig. 4.) depicts the chemical variability of primary plagioclase of Apliki Pillow Lavas. The majority ranges in composition from An70 to An50, falling in the fields of labradorite, while andesine and bytownite are rarely observed. They form tabular lath-shaped crystals and are associated with variably altered clinopyroxenes. Locally they are replaced by clays, calcite and/or zeolites.

Clinopyroxene is augite, while orthopyroxenes are rarely observed. The chemical composition of plagioclases and pyroxenes from the Apliki Pillow Lavas (Table 1.) are plotted on the corresponding diagrams (Fig. 4.). 


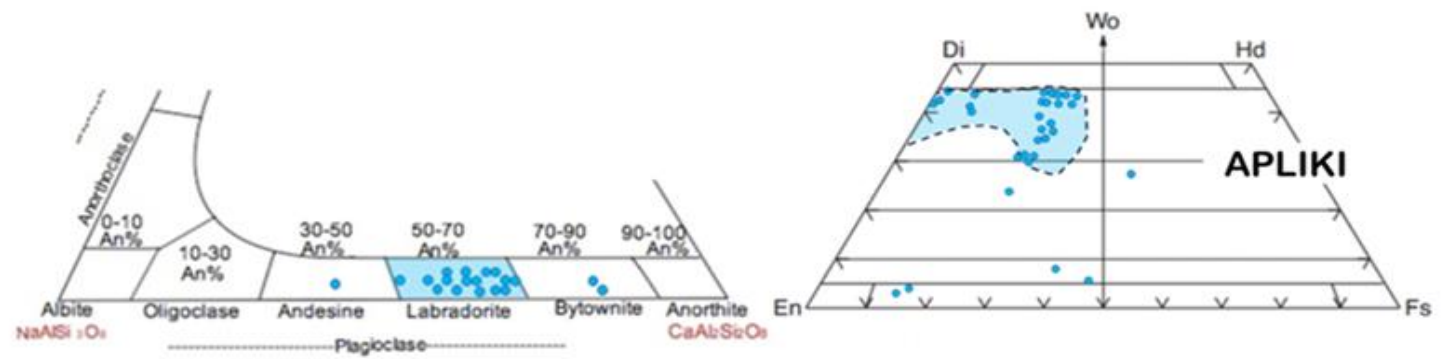

Fig.4. (a) Ternary classification diagram Ab-An-Or for plagioclase, showing the chemical variability of primary plagioclase of Apliki pillow lavas and (b) classification diagram $\mathrm{Di}-$ Hd-En-Fs for pyroxenes, showing the chemical variability of clinopyroxenes of Apliki pillow lavas $(\mathrm{Di}=$ diopside; $\mathrm{Hd}=$ hedenbergite; $\mathrm{En}=$ enstatite; $\mathrm{Fs}=$ ferrosilite; $\mathrm{Wo}=$ wollastonite).

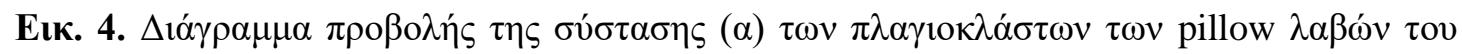

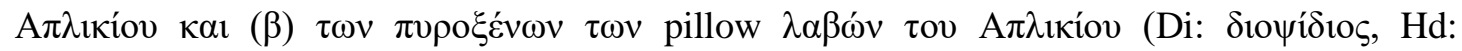

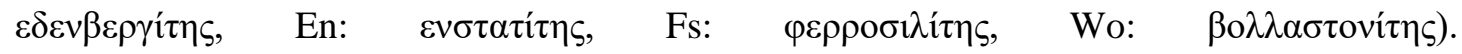
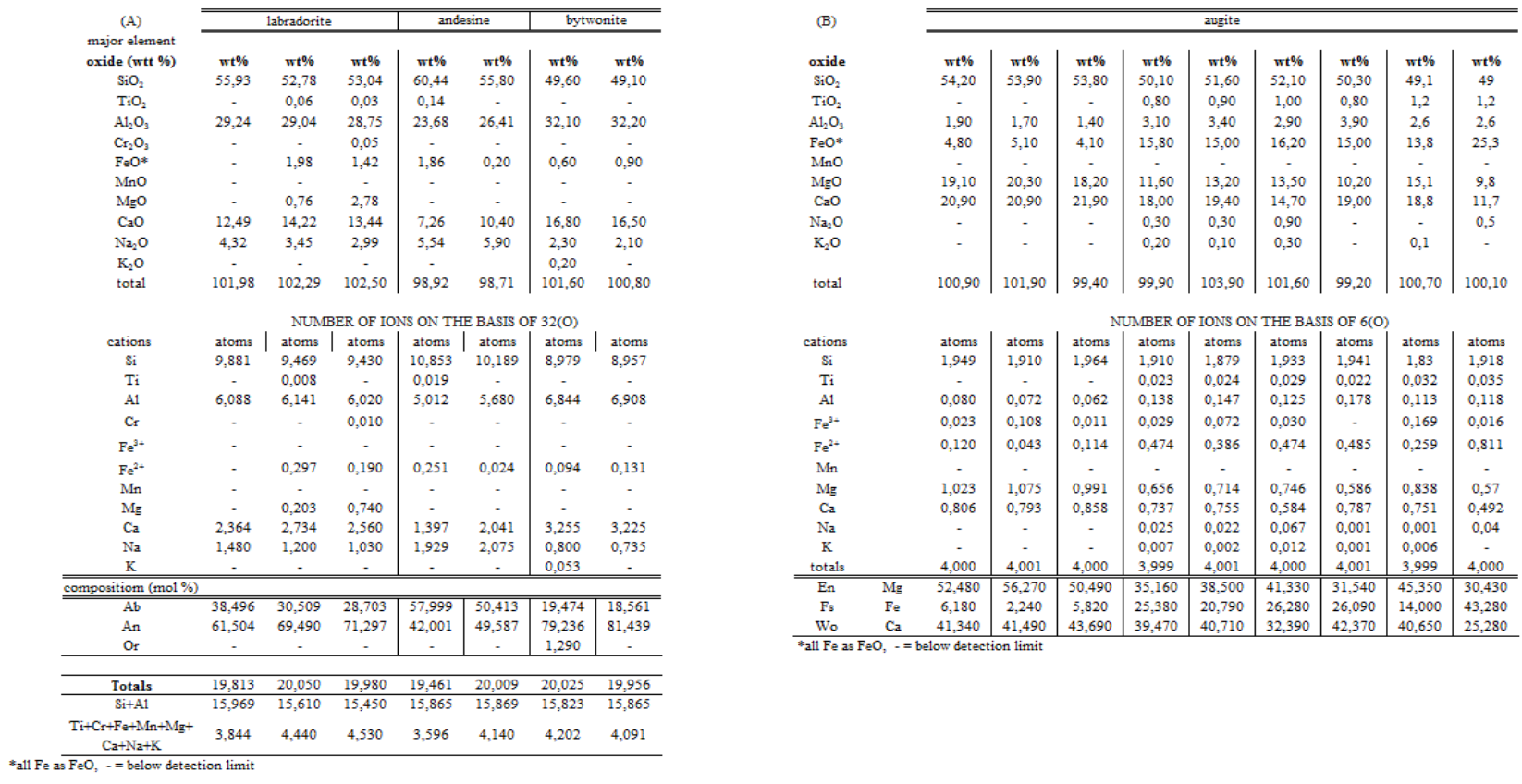

Table 1. Representative chemical analyses of plagioclase (A) and pyroxenes (B) in Apliki pillow lavas (complete chemical analyses in Antivachis 2014).

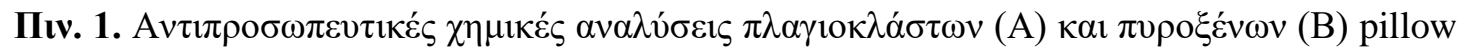

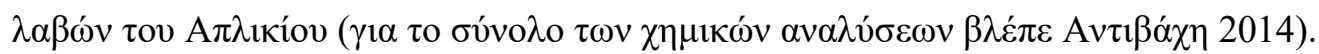

The metallic minerals are $\mathrm{Fe}, \mathrm{Fe}-\mathrm{Ti}$ and $\mathrm{Ti}$ oxides; specifically magnetite, ilmenite and rutile are scattered within the matrix of the lavas. Olivine occurs only as subhedral crystals.

Photomicrograph in Fig. 5. depicts the primary minerals of Apliki basaltic Pillow
Lavas. Lath-shaped plagioclase crystals intersect with each other and between them occur more or less altered clinopyroxenes crystals. The interstices between the existing grains are occupied by iron-titanium oxides and celadonite fills cracks and amygdules. 
Celadonite, clay minerals, calcite, analcime and quartz are the main "low temperature regional scale alteration" minerals of Apliki Lower Pillow Lavas, occurring within amygdules or dispersed within the matrix.

Celadonite, which is the predominant secondary mineral in the pillow lavas, usually replaces clinopyroxenes (Fig. 6.), with replacement commonly starting, most of the time, from the periphery of the crystals and proceeding to the core. Celadonite is accompanied by clay minerals, either within amygdules, as is shown in Fig.7B., or filling cavities between clinopyroxene crystals.

Clay minerals occur as replacements of plagioclase, clinopyroxenes and volcanic glass, within the groundmass of the lavas.

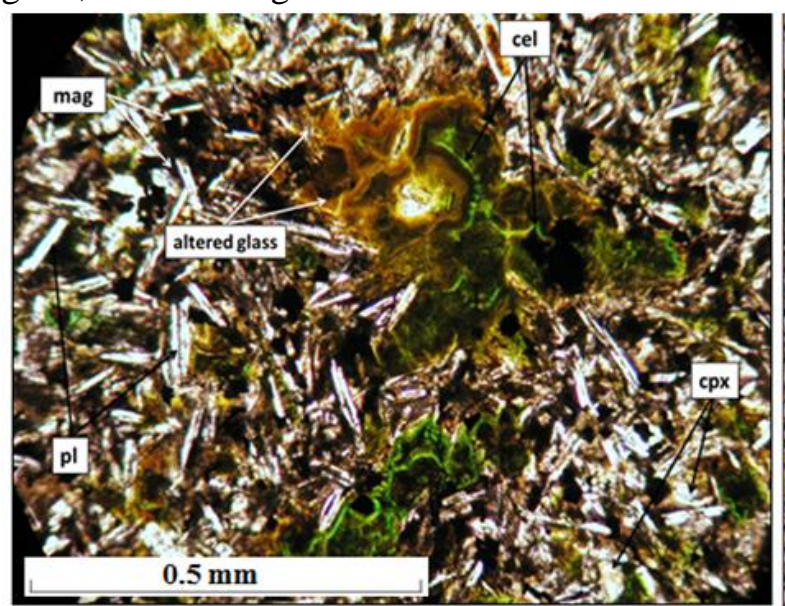

In addition, they are the predominant fracture- and vug-filling phases. Identification of clay minerals was based on combined XRD and microprobe analyses (Table 2.). Clay minerals identified in Apliki Pillow Lavas occur as a mixed aggregate of celadoniteglauconite-saponite and rarely as pure phases. Due to their nature their mineralogical identification is very difficult. Therefore their chemical compositions cannot be considered as reliable (Antivachis, 2014). Thus, taking into account their nature, they may be classified into four different mineral groups i.e. saponite, nontronite, celadonite-glauconite and mixed smectites group (Table 2.).

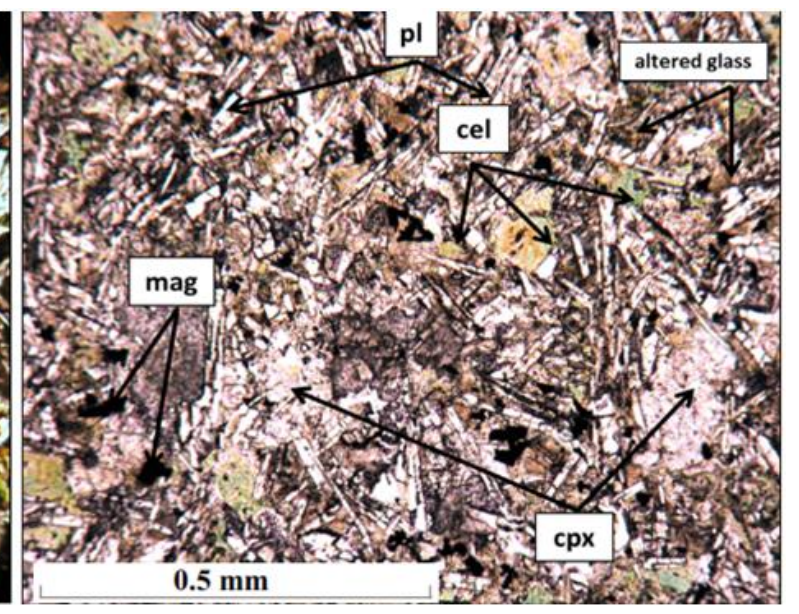

Fig. 5. Petrographic features of unmineralized Apliki pillow lavas. Lath-shaped plagioclase crystals intersect with each other and between them occur more or less altered clinopyroxenes crystals. The interstices between the existing grains are occupied by iron-titanium oxides, clay minerals and celadonite fills cracks and amygdules.

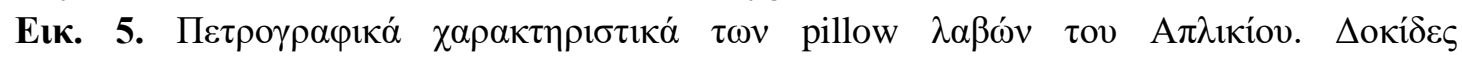

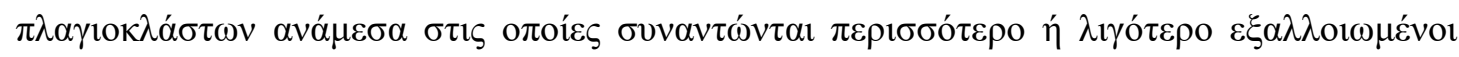

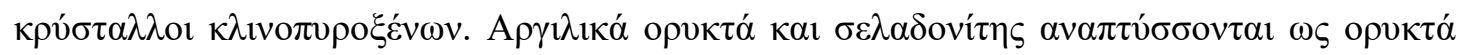

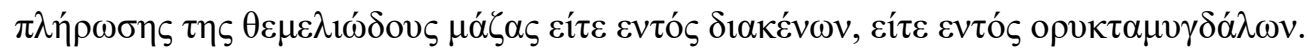

Saponite is characterized by high wt. \% $\mathrm{MgO}$ and $\mathrm{FeO}$, while the content of $\mathrm{K}_{2} \mathrm{O}$ does not exceed $1 \%$; it has also been identified within amygdules together with celadonite-glauconite and mixed smectites (Fig. 7B). Nontronite occurs only as a fracture- or vug-filling mineral. Celadonite and glauconite form fibrous crystals. Glauconite is typically of bright yellow-green colour and fills small veins and gaps, while celadonite is of bluegreen colour. Lastly, mixed smectites are characterized by relatively low iron content and constitute a mixture of beidellite-montmorillonite (dioctehedral 
smectites) and montmorillonite-illite (Fig.7A.).

Calcite occurs as large crystals between lath-shaped plagioclase.
Zeolites are deposited within cavities and amygdules and rarely as small veins replacing plagioclase.
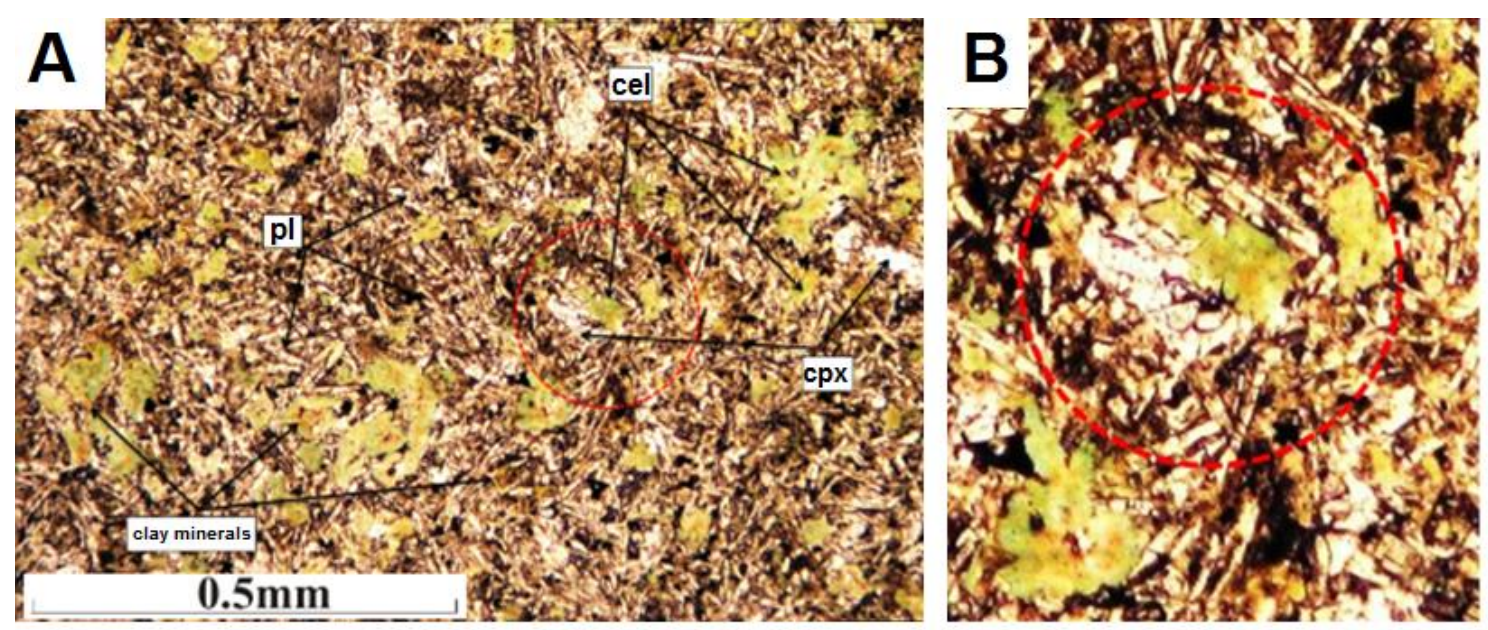

Fig.6. A. Petrographic features of Apliki pillow lavas. Lath-shaped plagioclase, clinopyroxene and clay minerals. B. Clinopyroxene crystals replaced by green clay minerals (celadonite).

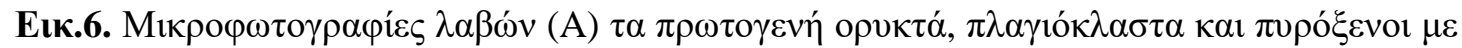

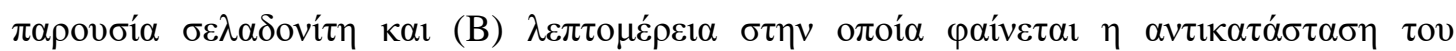

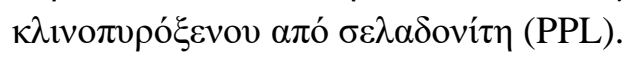
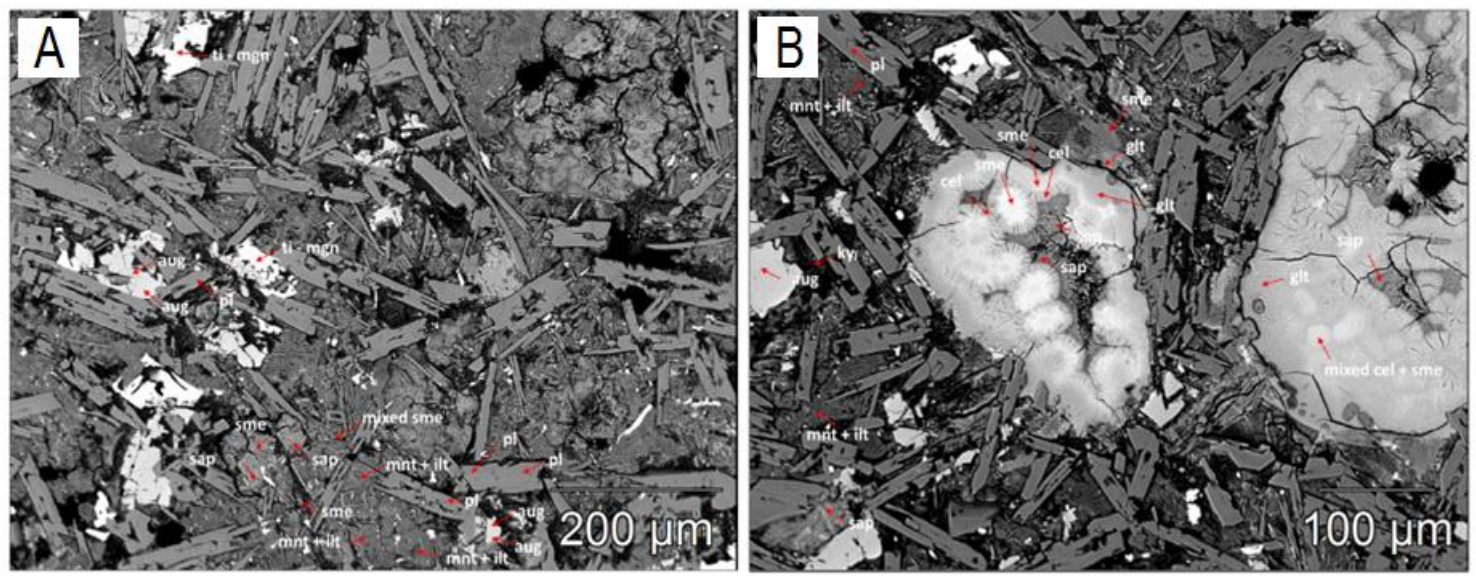

Fig.7. Back-scattered electron images of Apliki pillow lavas (A) Plagioclase and clinopyroxene phenocrysts along with clay minerals, (B) Amygdules filled by celadoniteglauconite-saponite assemblage.

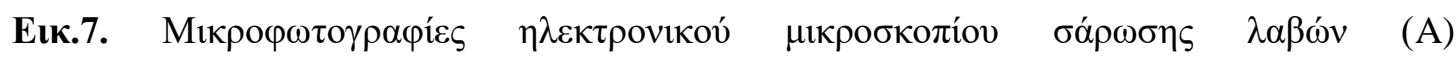

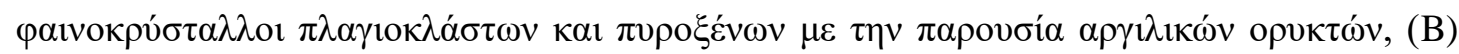

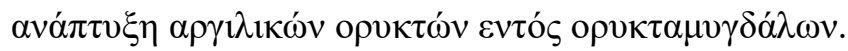




\begin{tabular}{|c|c|c|c|c|c|c|c|c|c|c|}
\hline \multirow[b]{2}{*}{ oxide } & \multicolumn{3}{|c|}{ saponite } & \multirow{2}{*}{\begin{tabular}{c|} 
non tronite \\
$\mathrm{wt} \%$
\end{tabular}} & \multicolumn{2}{|c|}{ celadonite } & \multicolumn{2}{|c|}{ glau conite } & \multirow{2}{*}{$\begin{array}{c}\begin{array}{c}\text { beidellite- } \\
\text { montmorillonite }\end{array} \\
\text { wt } \%\end{array}$} & \multirow{2}{*}{$\begin{array}{c}\text { montmorillonite- } \\
\text { illite }\end{array}$} \\
\hline & wt\% & $w t \%$ & wt\% & & wt\% & wt\% & "wt\% & "wt\% & & \\
\hline $\mathrm{SiO}_{2}$ & 42,62 & 42,07 & 42,86 & 40,98 & 50,71 & 51,07 & 50,81 & 49,63 & 60,39 & 49,69 \\
\hline $\mathrm{TiO}_{2}$ & 0,05 & - & 0,01 & 0,33 & 0,02 & 0,03 & 0,15 & 0,15 & 0,38 & 0,16 \\
\hline $\mathrm{Al}_{2} \mathrm{O}_{3}$ & 8,92 & 10,80 & 9,06 & 5,31 & 3,82 & 3,90 & 6,69 & 7,96 & 21,31 & 17,83 \\
\hline $\mathrm{Cr}_{2} \mathrm{O}_{3}$ & - & 0,01 & - & 0,02 & 0,02 & - & - & 0,01 & - & 0,02 \\
\hline $\mathrm{FeO}^{*}$ & 18,40 & 20,06 & 20,52 & 34,28 & 27,77 & 27,95 & 27,71 & 24,77 & 4,45 & 7,98 \\
\hline $\mathrm{MnO}$ & - & 0,38 & 0,26 & 2,45 & 0,23 & 0,11 & 0,18 & 0,21 & 0,01 & 0,07 \\
\hline $\mathrm{MgO}$ & 12,68 & 13,40 & 14,89 & 2,90 & 3,71 & 3,75 & 2,97 & 3,54 & 1,66 & 5,80 \\
\hline $\mathrm{CaO}$ & 2,09 & 2,16 & 1,99 & 1,52 & 0,78 & 0,85 & 1,21 & 1,79 & 4,04 & 4,97 \\
\hline $\mathrm{Na}_{2} \mathrm{O}$ & 0,07 & 0,08 & 0,06 & 0,03 & 0,00 & 0,04 & 0,07 & 0,13 & 5,01 & 3,43 \\
\hline $\mathrm{K}_{2} \mathrm{O}$ & 1,03 & 0,209 & 0,437 & 3,91 & 6,55 & 6,55 & 6,055 & 4,885 & 1,05 & 0,459 \\
\hline \multirow[t]{2}{*}{ total } & 85,85 & 89,17 & 90,08 & 91,71 & 93,60 & 94,25 & 95,85 & 93,07 & 98,30 & 90,42 \\
\hline & & $22(0)$ & & $20(0)$ & \multicolumn{2}{|c|}{$20(0)$} & \multicolumn{2}{|c|}{$20(0)$} & $20(0)$ & $20(0)$ \\
\hline cations & atoms & atoms & atoms & atoms & atoms & atoms & atoms & atoms & atoms & atoms \\
\hline $\mathrm{Si}$ & 6,780 & 6,480 & 6,558 & 6,254 & 7,132 & 7,129 & 6,929 & 6,850 & 6,90 & 6,392 \\
\hline $\mathrm{Ti}$ & 0,010 & - & 0,001 & 0,038 & 0,003 & 0,003 & 0,016 & 0,016 & 0,03 & 0,015 \\
\hline Al & 1,670 & 1,961 & 1,633 & 0,954 & 0,634 & 0,642 & 1,075 & 1,294 & 2,87 & 2,703 \\
\hline $\mathrm{Cr}$ & - & 0,001 & - & 0,002 & 0,002 & - & - & 0,001 & - & 0,002 \\
\hline $\mathrm{Fe}^{2+}$ & 2,450 & 2,584 & 2,626 & 4,375 & 3,266 & 3,263 & 3,161 & 2,859 & 0,43 & 0,858 \\
\hline $\mathrm{Mn}$ & - & 0,050 & 0,034 & 0,316 & 0,027 & 0,013 & 0,021 & 0,025 & 0,00 & 0,008 \\
\hline $\mathrm{Mg}$ & 3,010 & 3,076 & 3,395 & 0,659 & 0,779 & 0,781 & 0,603 & 0,729 & 0,28 & 1,112 \\
\hline $\mathrm{Ca}$ & 0,360 & 0,357 & 0,326 & 0,248 & 0,118 & 0,127 & 0,177 & 0,264 & 0,49 & 0,685 \\
\hline $\mathrm{Na}$ & 0,020 & 0,023 & 0,018 & 0,008 & - & 0,009 & 0,019 & 0,033 & 1,11 & 0,856 \\
\hline $\mathrm{K}$ & 0,210 & 0,041 & 0,085 & 0,761 & 1,175 & 1,166 & 1,053 & 0,860 & 0,15 & 0,075 \\
\hline Totals & 14,495 & 14,572 & 14,676 & 13,615 & 13,135 & 13,134 & 13,054 & 12,933 & 12,267 & 12,706 \\
\hline $\mathrm{Si}+\mathrm{A} 1$ & 8,000 & 8,000 & 8,000 & 8,000 & 7,766 & 7,771 & 8,000 & 8,145 & 8,000 & 8,000 \\
\hline $\mathrm{Al}+\mathrm{Ti}^{2}+\mathrm{Fe}^{2+}+\mathrm{Mg}+\mathrm{Mn}$ & 5,910 & 6,149 & 6,246 & 5,350 & 4,072 & 4,057 & 3,789 & 3,758 & 2,51 & 3,072 \\
\hline remaining elements & 0,586 & 0,471 & 0,462 & 1,333 & 1,321 & 1,316 & 1,270 & 1,183 & 1,758 & 1,624 \\
\hline
\end{tabular}

Table 2. Representative microprobe chemical analyses of clay minerals in Apliki pillow lavas (complete chemical analyses in Antivachis 2014).

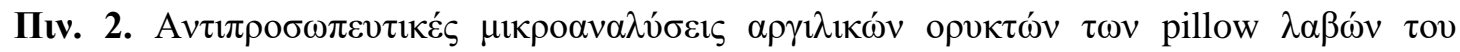

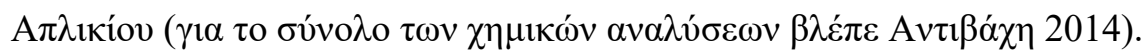

The main zeolite identified in the basaltic pillow lavas of the region is analcime, and is usually associated with clay minerals.

\subsection{Mineralization and hydrothermal alteration}

The Apliki stockwork-type sulphide mineralization is structurally controlled, bounded by two $\mathrm{N}-\mathrm{S}$ striking sub-parallel faults.

In the mineralized zone the following facies have been identified:

(a) A stockwork zone

(b) Veins of amorphous silica (silica zone)

(c) Massive veins of gypsum

(d) Oxidized vein of massive mineralization ("red zone") (e) Oxidation zone

A schematic geological section of northern wall of Apliki deposit is shown in Fig. 8. It includes the country rocks, the mineralized stockwork zone which is controlled by the two faults, veins of amorphous silica, massive veins of gypsum, oxidized vein of massive mineralization and oxidation zone. Additionally, in the central part of the mineralized zone, the drill hole AM 9 is identified.

The stockwork zone constitutes a complex network of quartz and jasper veins hosted within the brecciated pillow lavas (Fig. 8.) which are probably the result of explosive hydrothermal activity within the fault zone (Lydon and Galley, 1986). 


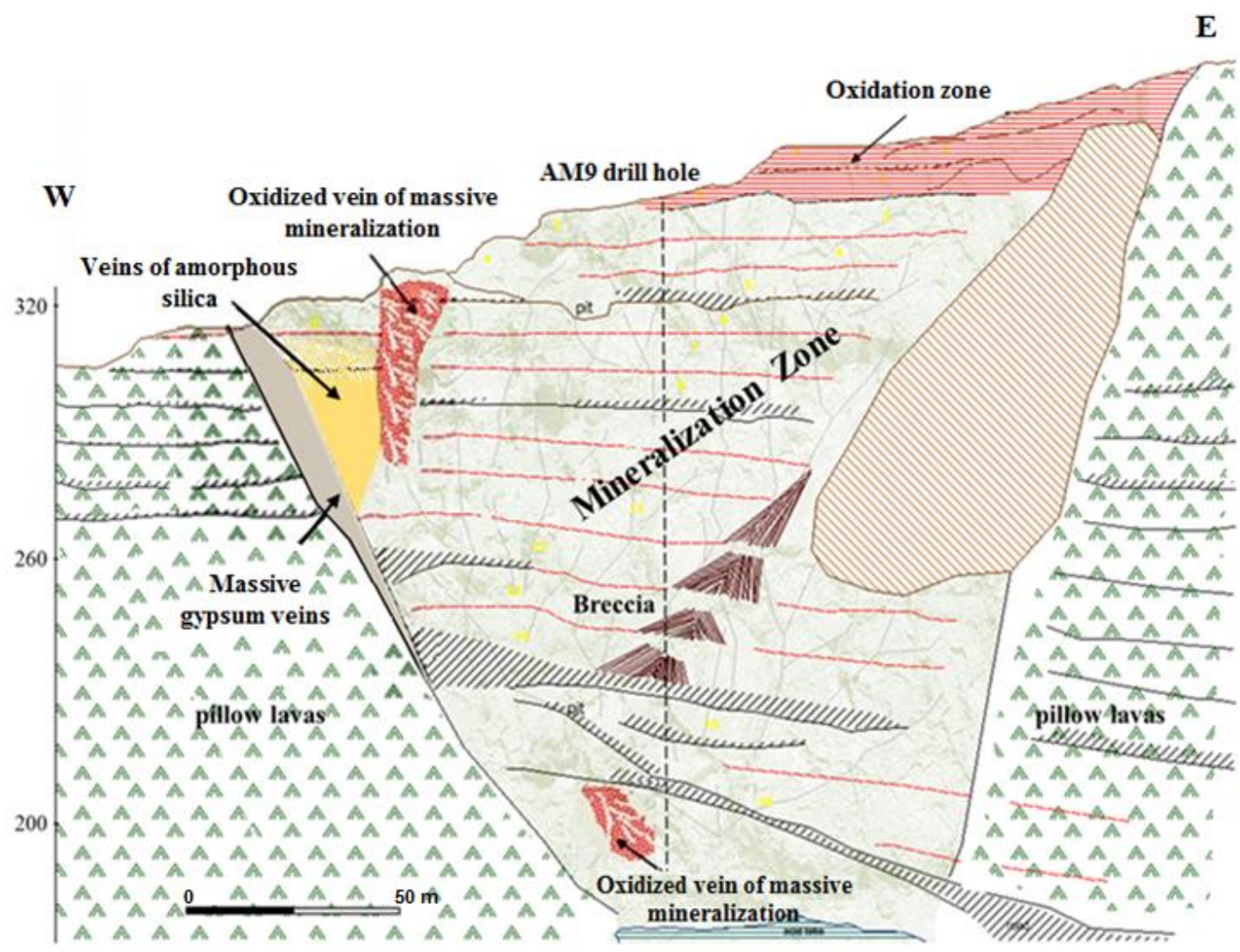

Fig. 8. Schematic geological section of northern part of Apliki deposit which includes the country rocks, the mineralized stockwork, veins of amorphous silica, massive veins of gypsum and the oxidation zone.

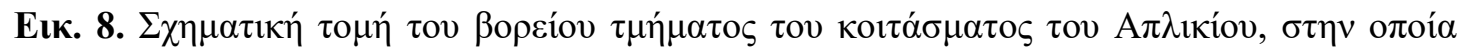

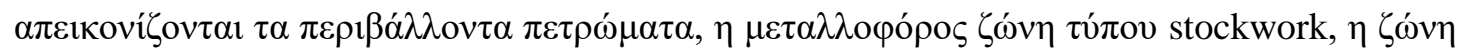

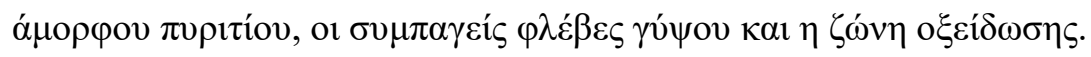

Brecciation is more pronounced in the upper parts of the mineralized zone, with the pillow structure to a large extent destroyed, and comprise rounded fragments of lava welded together by sulphide minerals and quartz. The basaltic brecciated Pillow Lavas from the upper part of the north wall of the opencut of the mineralized zone are depicted in Fig. 11A.. In these lavas primary magmatic minerals are not preserved.

The minerals of hydrothermally altered and brecciated lavas are chlorite, clay minerals, albite, iron and titanium oxides and quartz.

Chlorite is the predominant mineral amongst the non-metallic minerals which has been formed from the hydrothermal alteration of clinopyroxene and/or volcanic glass. Its chemical composition ranges from ripidolite to pycnochlorite (Table 3A.). The mineral often fills fractures in pyrite.

Clay minerals occur within the chloritized groundmass and it is sometimes impossible to distinguish them from each other (Table 3B.). They commonly replace volcanic glass and rarely occur as pure phases.

The albitization of magmatic plagioclase (labradorite-bytownite) led to the formation of pure albite. Oligoclase is rare. 


\begin{tabular}{|c|c|c|c|c|}
\hline A & & chior & & \\
\hline oxide & wt $\%$ & $w t \%$ & $w t \%$ & $\mathrm{wt} \%$ \\
\hline $\mathrm{SiO}_{2}$ & 29,53 & 26,09 & 26,55 & 27,12 \\
\hline $\mathrm{TiO}_{2}$ & 0,03 & 0,02 & 0,05 & 0,02 \\
\hline $\mathrm{Al}: \mathrm{O}_{3}$ & 20,92 & 20,68 & 21,84 & 20,86 \\
\hline $\mathrm{Cr}_{2} \mathrm{O}_{3}$ & 0,05 & 0,03 & 0,04 & 0,02 \\
\hline $\mathrm{FeO}$ & 17,38 & 16,65 & 19,88 & 21,45 \\
\hline $\mathrm{MnO}$ & 0.26 & 0,14 & 0,03 & 0,16 \\
\hline MgO & 19,85 & 18,87 & 17,44 & 1699 \\
\hline $\mathrm{CaO}$ & 0,16 & 0,15 & 0,06 & 0,09 \\
\hline $\mathrm{Na}_{2} \mathrm{O}$ & - & $\cdot$ & 0,03 & 0,01 \\
\hline $\mathrm{K}_{2} \mathrm{O}$ & 0,01 & - & - & 0,04 \\
\hline \multirow[t]{2}{*}{ total } & $\$ 8,19$ & $\$ 2,63$ & 85,92 & $\$ 6,67$ \\
\hline & & $28(0)$ & & \\
\hline cations & atoms & atoms & atoms & atoms \\
\hline $\mathrm{Si}$ & 5,878 & 5,571 & 5,523 & 5,642 \\
\hline $\mathrm{Ti}$ & 0,005 & 0,004 & 0,008 & 0,003 \\
\hline Al & 4,909 & 5,203 & 5,356 & 5,116 \\
\hline $\mathrm{Cr}_{\mathrm{r}}$ & 0,007 & 0,005 & 0,006 & 0,003 \\
\hline $\mathrm{Fe}^{\mathrm{2+}}$ & 2,893 & 2973 & 3,459 & 3,732 \\
\hline $\mathrm{Mn}$ & 0,043 & 0,025 & 0,006 & 0,027 \\
\hline $\mathrm{Mg}$ & 5,891 & 6,006 & 5,408 & 5246 \\
\hline $\mathrm{Ca}$ & 0,033 & 0,033 & 0,014 & 0,019 \\
\hline $\mathrm{Na}$ & - & - & 0,012 & 0,003 \\
\hline $\mathrm{K}$ & 0,002 & - & - & 0,011 \\
\hline Totals & 19,661 & 19.820 & 19,793 & 19.802 \\
\hline
\end{tabular}

\begin{tabular}{|c|c|c|c|c|c|}
\hline \multicolumn{2}{|c|}{ beidelite } & \multirow{2}{*}{$\begin{array}{c}\text { kaolinite-smectite } \\
\mathrm{wt} \%\end{array}$} & \multirow{2}{*}{$\begin{array}{c}\begin{array}{c}\text { beidelite- } \\
\text { mantmonillonite }\end{array} \\
\text { wt } \% \\
\end{array}$} & \multirow{2}{*}{$\begin{array}{c}\text { chlorite-smectite } \\
\mathbf{w t} \%\end{array}$} & \multirow{2}{*}{$\begin{array}{r}\text { kadinite } \\
\mathrm{wt} \% \\
\end{array}$} \\
\hline oxide & $w t \%$ & & & & \\
\hline $\mathrm{SSO}_{2}$ & 37,87 & 46,08 & 43,00 & 39,09 & 48,30 \\
\hline $\mathrm{TiO}_{2}$ & 0,01 & - & 0,02 & 0,02 & 0,02 \\
\hline $\mathrm{AkO}_{3}$ & 27,04 & 32,31 & 36,01 & 33,19 & 36,05 \\
\hline $\mathrm{Cr}_{2} \mathrm{O}_{3}$ & 0,02 & 0,01 & 0,01 & - & 0,01 \\
\hline $\mathrm{FeO}$ & 121 & 0.98 & 0,58 & 3,55 & 0,58 \\
\hline $\mathrm{MnO}$ & - & 0,01 & 0,02 & 0,01 & 0,02 \\
\hline $\mathrm{MgO}$ & 1,89 & 1,79 & 0,41 & 3,56 & 1,22 \\
\hline $\mathrm{CaO}$ & 294 & 3,47 & 4,18 & 2,68 & 3,63 \\
\hline $\mathrm{Na}_{z} \mathrm{O}$ & 097 & 1,14 & 1,92 & 1,26 & 1,54 \\
\hline $\mathrm{K}_{2} \mathrm{O}$ & 0,34 & 0,43 & 0,26 & 0,14 & 0,29 \\
\hline \multirow[t]{2}{*}{ total } & 72.29 & 86.22 & 86,41 & 83,49 & 91.65 \\
\hline & $20(0)$ & $20(0)$ & $20(0)$ & $20(0)$ & $18(\mathrm{O})$ \\
\hline cations & atoms & atoms & atoms & atoms & atoms \\
\hline $\mathrm{Si}$ & 5,750 & 5,838 & 5,466 & 5,234 & 5,168 \\
\hline $\mathrm{Ti}$ & 0,001 & - & 0,002 & 0,002 & 0,002 \\
\hline Al & 4,839 & 4,824 & 5,396 & 5,239 & 4,545 \\
\hline $\mathrm{Cr}$ & 0,003 & 0,001 & 0,001 & - & 0,001 \\
\hline $\mathrm{Fe}^{2+}$ & 0,154 & 0,104 & 0,061 & 0,398 & 0,052 \\
\hline Mn & - & 0,001 & 0,002 & 0,001 & 0,002 \\
\hline $\mathrm{Mg}$ & 0,428 & 0,337 & 0,078 & 0,711 & 0,194 \\
\hline $\mathrm{Ca}$ & 0,478 & 0,471 & 0,569 & 0,385 & 0,416 \\
\hline $\mathrm{Na}$ & 0,285 & 0.281 & 0,474 & 0,326 & 0,319 \\
\hline $\mathrm{K}$ & 0,065 & 0,069 & 0,042 & 0,023 & 0,039 \\
\hline Totals & 12,003 & 11,925 & 12,091 & 12,319 & 10,737 \\
\hline
\end{tabular}

Table 3. Representative Microprobe chemical analyses of chlorite (A) and clay minerals (B) in Apliki hydrothermal altered brecciated lavas (complete chemical analyses in Antivachis 2014).

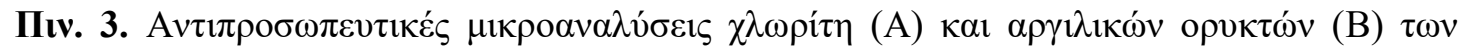

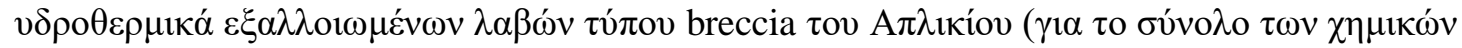

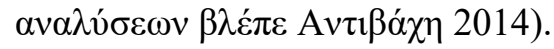

Calcite partially replaces plagioclase and clinopyroxene and occurs either as filling material within amygdules and voids, or within the groundmass. Anatase replaces iron-titanium oxides and particularly ilmenite.

The mineralogical assemblage (chlorite, albite, clay minerals and anatase) identified at Apliki suggests that the prevailing alteration in the mineralized zone is chloritization. The mineralogical assemblage identified at Apliki is clearly depicted in back-scattered electron images of hydrothermally chloritized lavas (Fig. 9.). The petrographic examination of samples indicates a mineral deposition sequence. Chlorite, albite and clay minerals are the first minerals formed and then quartz and pyrite filled vugs, veins and small cracks.

The hydrothermal alteration zonation is based on the mineralogical and geochemical study of 66 samples, covering the whole north wall of the opencut of the mineralized zone. The transition from one subzone to another is not clear and regarded more as a transition zone rather than as a clear contact (Fig. 10.). In conjunction with Fig. 8., Fig. 10. illustrates a schematic section of the northern wall of mineralized zone with the zonation of hydrothermal alteration.

The chloritic alteration can be spatially classified into three subzones of increasing intensity from the periphery to the core of the stockwork zone (hydrothermal alteration zonation) (Fig. 10.). These are:

(1) Smectitic, involving montmorillonite and illite, with limited presence of chlorite. This subzone can hardly be distinguished from the Lower Pillow Lavas.

(2) Chloritic - smectitic, with stronger presence of chlorite as a replacement of pyroxenes. 
(3) Chloritic, in which chlorite is the dominant mineral, with magmatic minerals absent.

In the upper parts of the mineralized zone weak silicification is detected.

The vein-like amorphous silica bodies (silica zone) and massive veins of gypsum develop in a $\mathrm{N}-\mathrm{S}$ orientation and occur in the western part of the mineralized zone (Fig. 8.). The main associates of the amorphous silica zone are kaolinite and $\mathrm{Na}-, \mathrm{Na}-\mathrm{Mg}$ and $\mathrm{Mg}$-sulphates.
Additionally, an oxidized vein of massive mineralization occurs in the northwest and southwest part of the mineralized zone (Fig. 8.). Goethite, jarosite and natrojarosite are the predominant minerals, while $\mathrm{Fe}-\mathrm{Ti}, \mathrm{Pb}, \mathrm{Cu}$, and $\mathrm{Zn}$ oxides are accessories.

The stockwork zone is overlain by a zone of limited oxidation (not exceeding 30 meters) with the formation of hematite and goethite, accompanied by tenorite and cuprite minerals (Fig. 2a, 8, 10.).

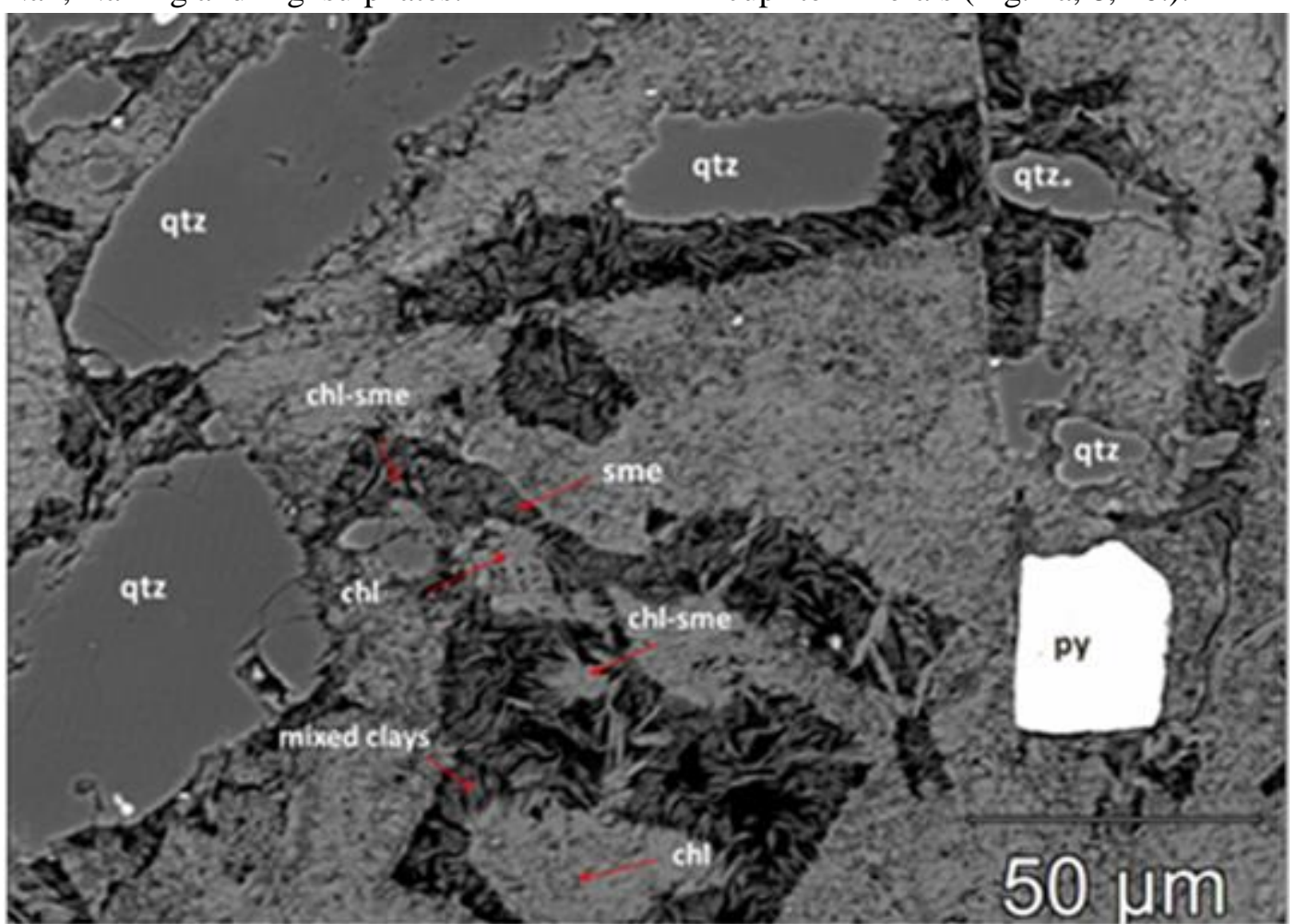

Fig. 9. Back-scattered electron images of hydrothermally brecciated chloritized lavas with the intense presence of smectites. The quartz is replaced by the smectite as indicated by the corroded outlines.

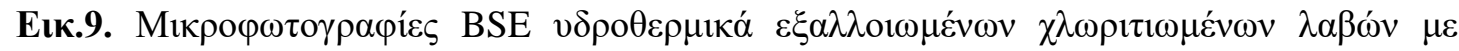

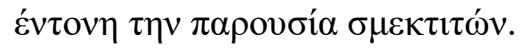

\subsection{Jasper}

Jasper is widely present in the brecciated lavas, either in the form of veins or as open-space fillings between pillows (Fig. 11B.).

Quartz, goethite and hematite are the main components of the jasper, together with minor amounts of clays and carbonate. All samples of jasper contain sulphide minerals, predominantly pyrite with minor sphalerite and chalcopyrite. Jasper displays a variety of macroscopic textures that range from massive, laminated to brecciated. It is characterized by dense aphanitic texture that reflects uniform distribution of hematite and quartz. Jasper in Apliki is made up of hematite-rich laminae $1-5 \mathrm{~mm}$ thick. Colour distribution is characteristic, with individual laminae 
ranging from dark red to orange, probably due to variations in iron content or the nature of the iron mineral (hematite, limonite, goethite).

\section{Ore Mineralogy and chemistry}

Pyrite, marcasite and chalcopyrite are the predominant ore minerals whereas bornite, sphalerite, galena and barite are accessories (Fig. 12.). Their crystals are characterized by considerable variability ranging from hypidiomorphic to allotriomorphic. Porous and cataclastic texture is common.

Pyrite is universally present in the form of veins or disseminations in the hydrothermally altered host rocks. Its crystals do not exceed $0.5 \mathrm{~mm}$. The mineral frequently contains numerous inclusions or growths of chalcopyrite, sphalerite, pyrrhotite, cubanite and Fe-Ti oxides, whereas inclusions of talnakhite, haycockite and fukuchilite are rarely observed.

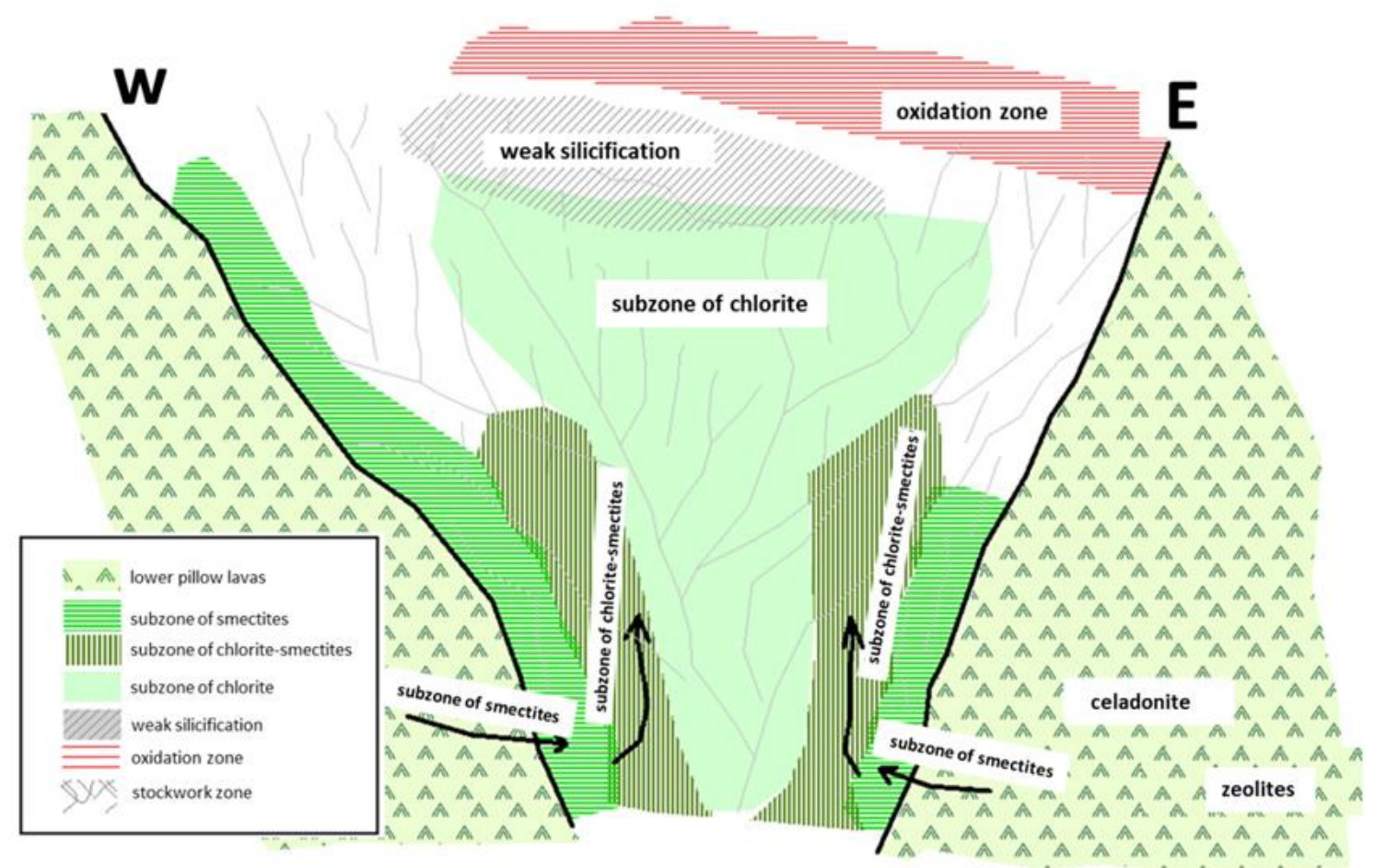

Fig. 10. Schematic cross-section of the Apliki massive sulphide orebody and associated stockwork, showing the zonation of hydrothermal alteration.

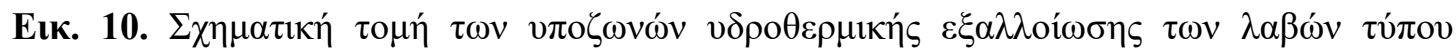

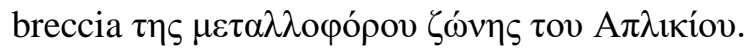



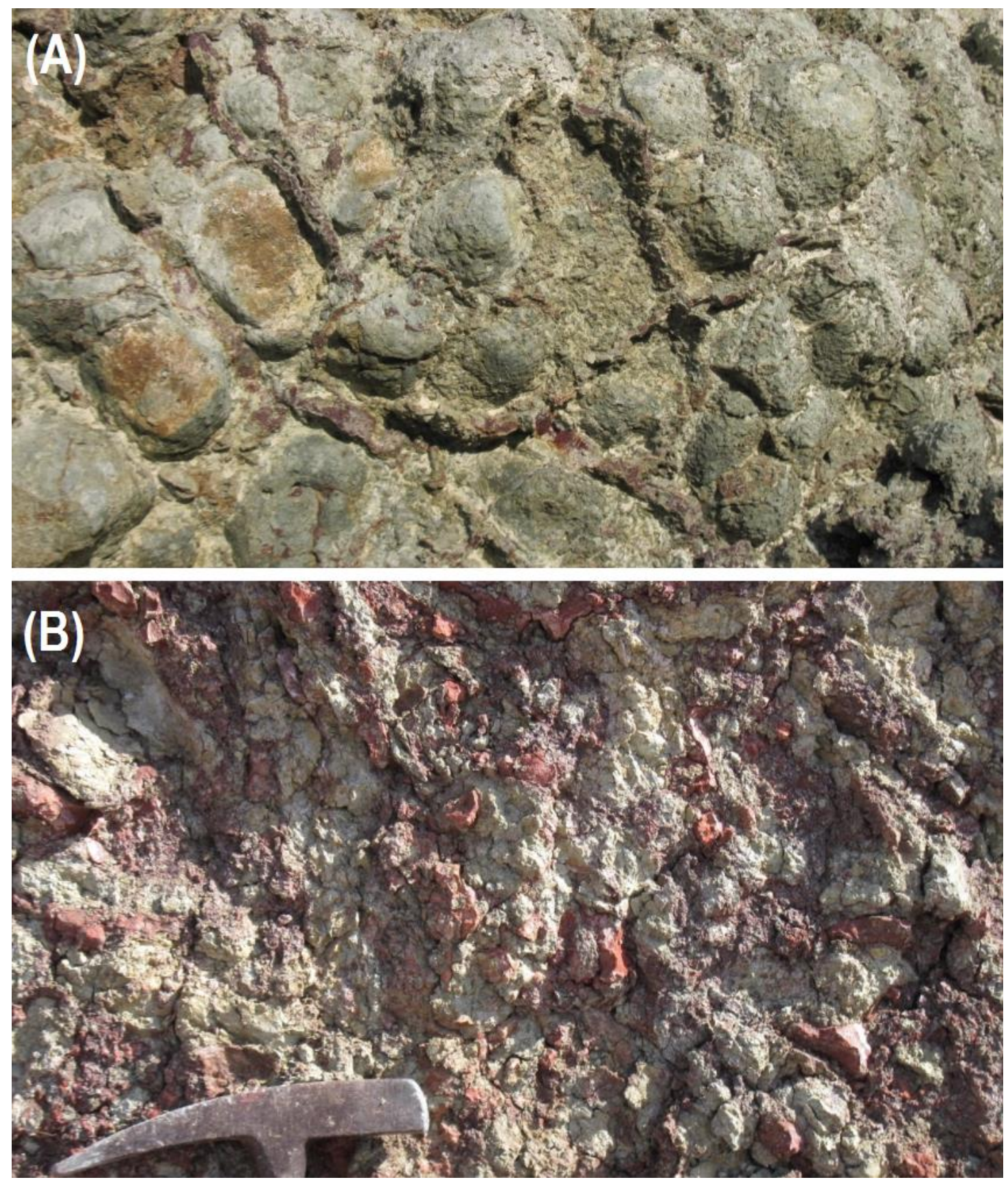

Fig. 11. (A) Basaltic brecciated pillow lavas from the upper part of the north wall of mineralized zone and (B) Jasper veins crosscut the brecciated pillow lavas.

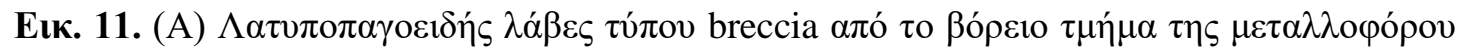

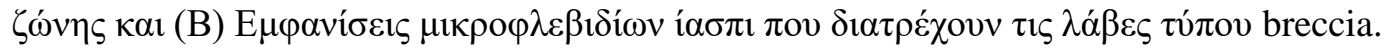



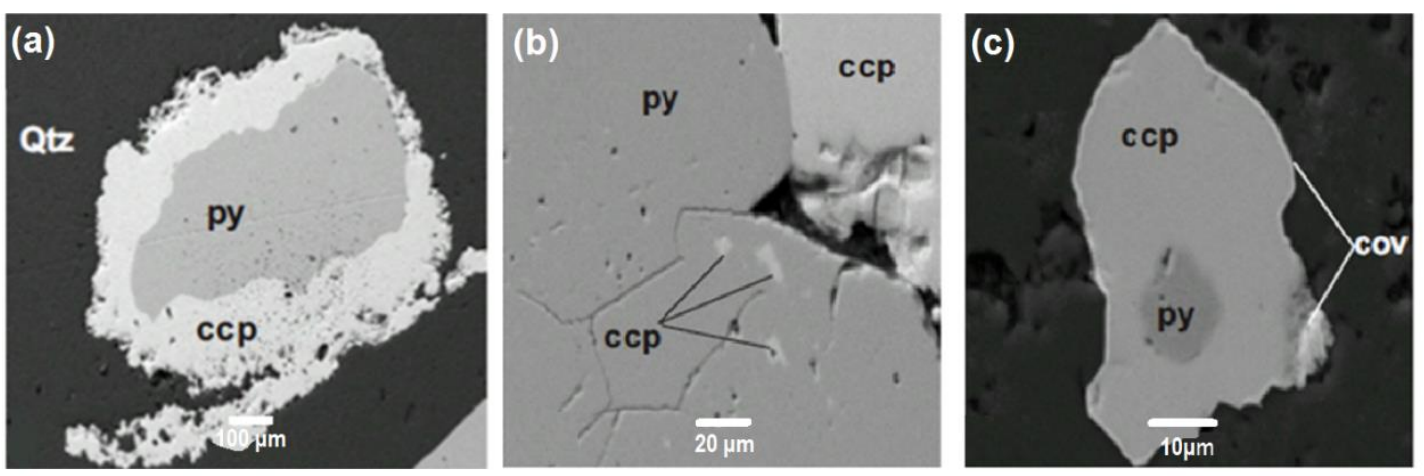

Fig. 12. Back-scattered electron images of pyrite (py) and chalcopyrite (ccp) crystals; the main mineralogical components of semi-massive and disseminated sulphide Apliki ore: (a) pyrite (py) enclosed in chalcopyrite (ccp), (b) inclusions of chalcopyrite (ccp) in pyrite (py) matrix and (c) peripheral replacement of chalcopyrite (ccp) by covellite (cov).

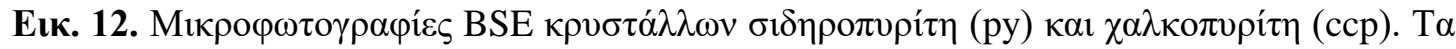

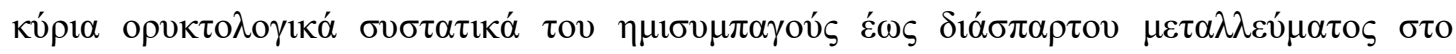

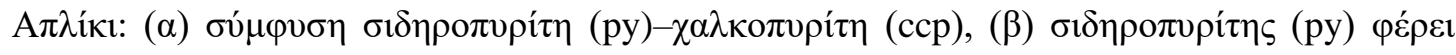

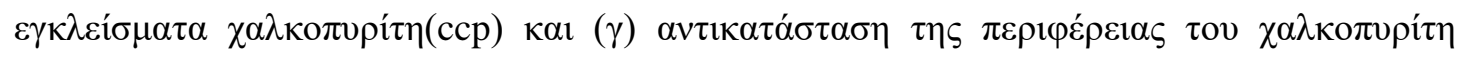

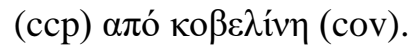

Quartz is the principal gangue mineral in pyrite. The size of inclusions ranges from $<3 \mu \mathrm{m}$ to $20 \mu \mathrm{m}$.

Microanalyses of pyrite reveal that copper ranges from 0.1 to 0.3 wt. $\%$, with arsenic and cobalt ranging from 0.1 to $0.5 \mathrm{wt} \%$. Nickel ranges from traces up to $1.5 \mathrm{wt}$. \%. Chalcopyrite is the second most abundant metallic mineral. It occurs in the form of irregular crystals of variable size filling the interspace between pyrite crystals and it is commonly associated with other minerals. Chalcopyrite exhibits either a close paragenetic relationship with pyrite or contains inclusions of sphalerite, talnakhite, idaite and rarely mooihoekite within its matrix. Replacement of chalcopyrite by covellite and chalcocite is also documented and is clearly related to supergene processes.

The chemistry of chalcopyrite indicates that the content of cobalt and nickel ranges from 0.1 to 0.4 wt. $\%$ and 0.1 to 0.5 wt. $\%$ respectively. Arsenic and silver contents are very limited and do not exceed 0.2 and 0.1 wt. \% respectively. Zinc content exceeds $0.6 \mathrm{wt}$ \% in semi-massive ore samples contrary to the disseminated ones whose respective content is below detection.

Galena-a rather uncommon mineral with allotriomorphic crystals-is usually completely oxidized and replaced by anglesite.

Bornite was only found in samples of drill hole AM9. Specifically, from 31 to 38 meters the periphery of chalcopyrite is replaced by bornite, while from 50 to 57 meters chalcopyrite

contains growths of bornite.

Sphalerite is the last, amongst the ore minerals of the stockwork zone, to form and appears as inclusions within either pyrite or chalcopyrite. Trace elements identified within the sphalerite are iron, manganese, cadmium and rarely copper. Chemical analyses indicate that cadmium content ranges from 0.1 to 0.9 wt. \%, while the respective values for manganese are 0.05 to 0.7 wt. $\%$. Pure sphalerite is rarely detected, since zinc always replaces iron. The variation of iron content (from 
4.2 to 19.2 wt. $\% \mathrm{FeS}$ ) follows the prevailing trend of Cyprus-type ore deposits e.g. Mathiatis, Mousoulos and South Mathiatis (Hannington et al., 1998; Adamides, 2014). It demonstrates deposition in a wide range of physicochemical conditions which has been interpreted as the result of variations in $\alpha_{\text {s, }}$, temperature and/or pressure (Barton et al., 1977; Einaudi et al., 2003).

Goethite, hematite, chalcocite, covellite and $\mathrm{Fe}-, \mathrm{Cu}-, \mathrm{Pb}-, \mathrm{Al}-$ and $\mathrm{Ca}-$-sulphates were formed in the supergene environment.

The remaining Apliki semi-massive to disseminated sulphide ore is characterized by sulphur and copper content ranging between 0.1 to 16 wt. $\%$ and 0.01 to 3.5 wt. \% respectively. Pyrite, chalcopyrite and marcasite are the predominant minerals, a fact which is depicted in the copper, iron and sulfur concentrations in conjunction with the ones of $\mathrm{Cd}, \mathrm{Co}, \mathrm{Cu}$, $\mathrm{Pb}, \mathrm{Zn}, \mathrm{Ag}, \mathrm{As}, \mathrm{Au}, \mathrm{Hg}, \mathrm{Ni}$ and $\mathrm{Sb}$ being distinctly lower (Table 4.). The $\mathrm{SiO}_{2}$ content is particularly high (from 33 to 69 wt. \%) throughout the mineralized zone and is closely related to the quartz and jasper veining which characterizes the stockwork zone. The gold grade in Apliki in pyrite concentrates ranges from 320 to $810 \mathrm{mg} / \mathrm{kg}$ (Antivachis, 2014).

In order to evaluate the spatial distribution of major elements, in both the northern and southern wall of mineralized zone, mapping and geographic analysis MapInfo 11.0 software and Vertical Mapper, with interpolation natural neighbor method were used.

\begin{tabular}{|c|c|c|c|c|c|c|c|c|c|c|c|c|c|c|c|}
\hline Cyprus & $\begin{array}{c}\text { type of } \\
\text { mineralization }\end{array}$ & $\mathrm{Ag}$ (ppm) & As (ppm) & $\mathrm{Au}(\mathrm{ppb})$ & $\mathrm{Cd}(\mathrm{ppm})$ & $\mathrm{Co}(\mathrm{ppm})$ & $\mathrm{Cu}(\%)$ & $\mathrm{Fe}(\%)$ & $\mathrm{Ni}(\mathrm{ppm})$ & $\mathrm{Pb}(\mathrm{ppm})$ & $\mathrm{S}(\%)$ & $\mathrm{Se}(\mathrm{ppm})$ & $\mathrm{Sb}(\mathrm{ppm})$ & $\mathrm{Zn}(\%)$ & references \\
\hline Skouriotissa & massive sulphide & 5 & 74 & 500 & - & 359 & 2,78 & 45,4 & 20 & $<100$ & - & 296 & 3 & 0,02 & $\begin{array}{c}\text { Kortan (1970). } \\
\text { Hannington et at (1988) }\end{array}$ \\
\hline Mavrovouni & massive sulfhide & 7 & 170 & 1050 & - & 410 & 3,69 & 39,2 & - & - & - & 330 & - & 0,8 & Kortan (1970) \\
\hline Mathin tis & massive sulphide & 4 & 160 & 800 & 29 & 54 & 0,17 & 39,5 & 33 & 97 & 48 & 20 & 11 & 0,3 & $\begin{array}{l}\text { Constantinou \& Govett } \\
\text { (1973). Hannington ot } \\
\text { al (1998) }\end{array}$ \\
\hline Sha & massive sulphide & 10 & 657 & 1000 & 27 & 20 & 1,9 & 29.4 & $<10$ & 94 & 36,7 & 26 & 20 & 1,2 & Hannington et at (1998) \\
\hline Agr okipia & massive sulphide & 1 & 201 & 135 & 1 & 190 & 0,07 & 40 & $<10$ & 30 & 46,9 & 144 & 3 & 0,03 & Hennington et at (1998) \\
\hline Agrolipia B & stockw ork & $<5$ & 694 & 160 & 14 & 133 & 0,04 & 45,5 & 36 & - & 19 & 7 & - & 0,05 & $\begin{array}{l}\text { Const antinou \& Govett } \\
\text { (1973), Herrig (1988). } \\
\text { Hannington et al (1998) }\end{array}$ \\
\hline Apiki & stockw ork & 0,2 & 18,6 & 60 & 11,8 & 83 & 0,6 & 13,6 & 58 & 9,8 & 3,6 & 10,9 & 0,1 & 0,03 & thisstudy \\
\hline A piki & semi-massive & 0,5 & 51 & 510 & 2,9 & 99 & 2, & 18,3 & 55 & 10 & 10,3 & 31 & 7 & 0,03 & thisstudy \\
\hline G MOUND & $\begin{array}{c}\text { type of } \\
\text { mineralization }\end{array}$ & $\mathrm{Ag}(\mathrm{ppm})$ & As (ppm) & $\mathrm{Av}(\mathrm{ppb})$ & $\mathrm{Cd}(\mathrm{ppm})$ & $\mathrm{Co}(\mathrm{ppm})$ & $\mathrm{Cu}(\%)$ & $\mathrm{Fe}(\%)$ & $\mathrm{Ni}(\mathrm{ppm})$ & $\mathrm{Pb}(\mathrm{ppm})$ & $\mathrm{S}(\%)$ & $\mathrm{Se}(\mathrm{ppm})$ & $\mathrm{Sb}(\mathrm{ppm})$ & $\mathrm{Zn}(\%)$ & references \\
\hline TAG MOUND & stockw ork & $<1$ & 33 & 214 & 3 & 285 & 1,9 & 28,6 & $<10$ & 6 & 36,6 & 17 & $<1$ & 0,1 & Hennington et at (1998) \\
\hline Alvin samples & massive sulphide & 37 & 99 & 1430 & 70 & 2 & 4,6 & 32,7 & 29 & 480 & 40,7 & 11 & 9 & 3,3 & $\begin{array}{l}\text { Famington et at } \\
\text { (1991). T wey et at } \\
(1995)\end{array}$ \\
\hline Oman & $\begin{array}{c}\text { type of } \\
\text { mineralization }\end{array}$ & $\mathrm{Ag}(\mathrm{ppm})$ & As (ppm) & $\mathrm{Av}(\mathrm{ppb})$ & $\mathrm{Cd}(\mathrm{ppm})$ & $\mathrm{Co}(\mathrm{ppm})$ & $\mathrm{Cu}(\%)$ & $\mathrm{Fe}(\%)$ & $\mathrm{Ni}(\mathrm{ppm})$ & $\mathrm{Pb}(\mathrm{ppm})$ & $\mathrm{S}(\%)$ & $\mathrm{Se}(\mathrm{ppm})$ & $\mathrm{Sb}(\mathrm{ppm})$ & $\mathrm{Zn}(\%)$ & references \\
\hline Lassail & massive sulphide & 8 & 7 & - & - & 235 & 3,75 & 47,1 & 75 & 25 & - & - & - & 0,05 & \begin{tabular}{|l} 
There et at. (1984). Fere th \\
al (1986)
\end{tabular} \\
\hline Rakah & massive sulphide & 25 & 5100 & - & - & 256 & 7,7 & 43,7 & 80 & 423 & 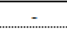 & - & 199 & 1,2 & \begin{tabular}{|l|l|} 
Lescyyer of at $(1988)$ \\
\end{tabular} \\
\hline Aarja & massive sulphide & 13 & 280 & - & 185 & 80 & 5,8 & 26,8 & 45 & 145 & - & $\therefore$ & - & 0,05 & $\begin{array}{l}\text { Irer et at. (1984), Frer et } \\
\text { at }(1986)\end{array}$ \\
\hline Rakah & stockw ork & 2 & 245 & - & - & 130 & $>1,5$ & 21,7 & 110 & 27 & - & - & 5 & 0,29 & Lescuyer et at (1988) \\
\hline Bayda & stockw ork & - & 50 & - & - & 130 & 2,65 & 32,5 & 33 & 61 & - & - & - & 0,29 & $\begin{array}{c}\text { Tier et al (1984). Fer et } \\
\text { at. (1986) }\end{array}$ \\
\hline Al Ajal & stockw ork & $<1$ & 36 & - & - & 180 & 0,97 & 17,8 & 117 & 10 & - & - & $<5$ & 0,07 & Lescuyer et at (1988) \\
\hline ayal-as- Safin & stockw ork & $<1$ & 11 & - & - & 62 & 0,34 & 9,4 & 149 & 8 & - & - & $<5$ & 0,02 & Lescuyer et al (1988) \\
\hline
\end{tabular}

Table 4. Ore grade of selected ophiolite-hosted massive sulphide deposits in Cyprus, TAG (TransAtlantic Geotraverse) and Oman.

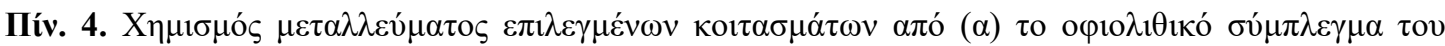

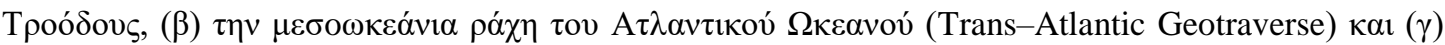

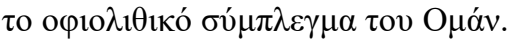




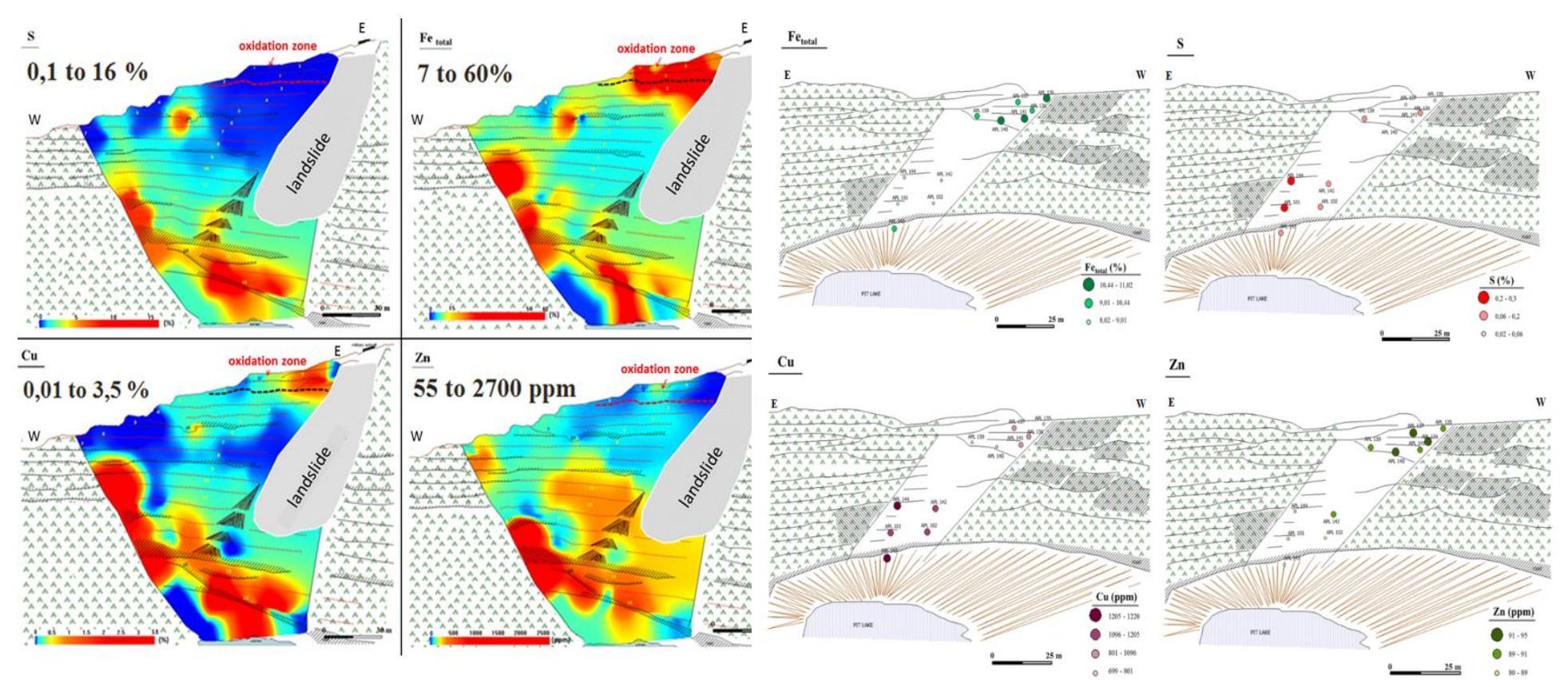

Fig.13. Element distribution $[\mathrm{S}(\%), \mathrm{Fe}(\%), \mathrm{Cu}(\mathrm{ppm})$ and $\mathrm{Zn}(\mathrm{ppm})]$ in the (a) northern and (b) southern wall of the mineralized zone.

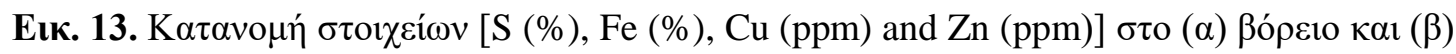

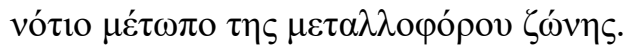

The spatial distribution (Fig. 13A.) of iron, sulphur and zinc in the stockwork zone in the northern part of the opencut is almost identical with those of copper. The highest copper content which reaches $3.5 \mathrm{wt}$ \%, is found in semi-massive ore (in the lower levels of northern wall of the deposit) and in a wide area along the western fault (Fig. 13a.), while in the southern wall of the opencut copper does not exceed $1220 \mathrm{ppm}$ (Fig. 13b.). It is noted that remarkably high copper concentrations are recorded in the oxidation zone as well (from 0.06 to $>1 \%$ ), a fact indicating that copper is not leached and a substantial part of it still remains.

\section{Discussion - Conclusions}

The Apliki deposit is hosted within the Lower Pillow Lavas of the Troodos ophiolite. Similar mineralogical assemblages of secondary minerals and phyllosilicates (clay minerals and micas), zeolites, calcite and quartz to those occurring at Apliki have been recorded in other locations of the Troodos ophiolite complex (Gillis and Robinson, 1985; 1988; 1990). Additionally, the presence of clay minerals, mainly as a mixture of components (celadonite-glauconitesaponite) and not as pure phases with a very limited participation of nontronite, is in agreement with the findings of workers on Troodos (Gallahan and Duncan, 1994; Kelman, 1999).The secondary minerals identified at Apliki, according to Alt and Honnorez (1984), Alt et al. (1986) and Gillis and Robinson (1988; 1990), constitute a low-temperature regional scale alteration assemblage with phyllosilicates being typically the most abundant, depending on local conditions. Apliki represents typical Cyprus type ore deposit and constitutes an example of structurally controlled stockwork type mineralization. It is inferred from the nature of the remaining mineralization at Apliki, that both the massive sulphide zone as well as the richer part of the stockwork zone have been removed by previous mining. As the massive sulphide zone has been removed, the bulk of the 
examined mineralization comprises the associated stockwork zone. This is characterized by pyrite and chalcopyrite, with subordinate marcasite and sphalerite as the main ore minerals within the brecciated Pillow Lavas whose dominant alteration is chloritization.

Chlorites from Apliki stockwork zonewith a ratio of $\mathrm{Fe} /(\mathrm{Fe}+\mathrm{Mg})$ ranging from 0.20 to 0.49 - follow a similar trend with the propylitized Pillow Lavas of similar deposits (Fig. 14.). Specifically, their chemical composition is consistent with the ones of TAG (Trans-Atlantic Geotraverse), Galapagos Rift and EPR $13^{\circ} \mathrm{N}$ (Alt et al., 1999; Alt, 1999).

At Apliki, jasper crosscuts the brecciated lavas throughout the stockwork zone. It is common in the stockwork zone of Cyprus-type massive sulphides
(Hannington et al., 1998) and it is generally accepted to be the result of lowtemperature hydrothermal activity interacting with seawater associated with existing fault zones (Duhig et al., 1992a; Hannington et al., 1998; Grenne and Slack, 2003a).

The ore chemistry and its spatial distribution exhibit an enrichment close to the western fault as well as at areas where the semi-massive ore is present, reflecting the existing mineralogical components with high concentration of $\mathrm{Fe}, \mathrm{Cu}$ and $\mathrm{S}$. This fact probably demonstrates that (a) the western fault was the major controlling structure through which, as the major channelway, the high-temperature fluids moved upwards and (b) the eastern fault represents the gradational passage into the unaltered Lower Pillow Lavas.

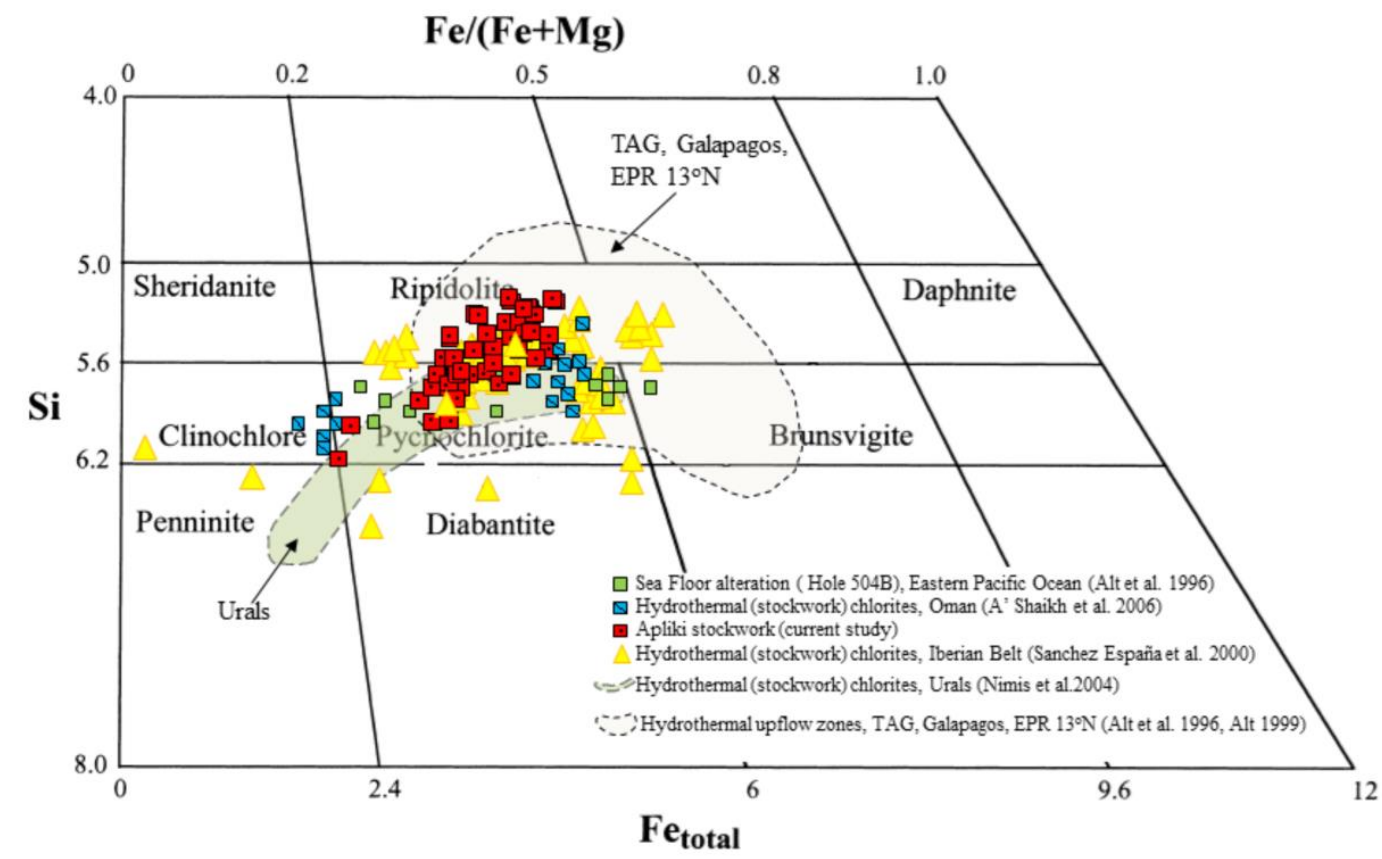

Fig.14. Classification diagram for chlorites from the Apliki deposit compared to similar hydrothermal stockwork-type chlorites, which are also plotted (classification after Hey, 1954).

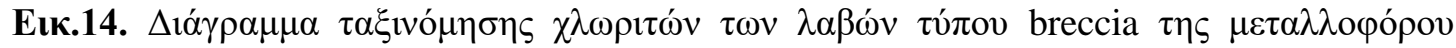

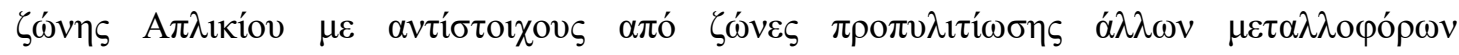

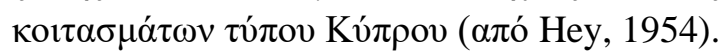

A comparison of the remaining part of the Apliki orebody-after the exploitation-with other VHMS deposits, like TAG Mount
(Hannington et al., 1998), Oman (Rakah, Bayda, Al Ajal Hayal-As-Safil; Lescuyer et al., 1988; Ixer et al., 1984; 1986), and 
other Cyprus-type deposits from Cyprus (e.g. Agrokipia B; Constantinou and Govett, 1973; Herzig, 1988; Hannington et al., 1998), demonstrates that it is typified by low concentration of all the elements with the exception of $\mathrm{Cu}$ (the average concentration is $0.6 \%$ in the stockwork zone and $2.1 \%$ in semi-massive ore). Copper content of Apliki stockwork type mineralization is comparable even with corresponding deposits with massive ore (e.g. Mathiatis $0.17 \%$, Agrokipia $0.07 \%$ and Sha 1.9\%) (Constantinou and Govett, 1973; Hannington et al., 1998).

The mineralogy of the host rock plays a significant geochemical role in the development of the gangue and ore mineral assemblages occurring in the oxidation zone (William, 2000). At Apliki, the limited oxidation, the high copper content and its limited mobility is the outcome of the existing disseminated mineralization characterized by insufficient available pyrite for the production of low-pH supergene solutions, which could lead to the formation of an extensive oxidation zone. The mineralogical constituents of the zone, iron oxides and hydroxides with cuprite as the predominant copper oxide, demonstrate neutral to alkaline $\mathrm{pH}$ weathering environment conditions. Copper in such an environment is relatively immobile. Due to the fact that copper grades in the Apliki oxidation zone are essentially the same as those in the hypogene protolith, it is surmised that the Apliki deposit constitutes a non-typical case with in situ oxidation of sulphide ore and limited copper transport. Similar cases have been recorded in Chile, Panama, Mexico and India (Williams et al., 1999; William, 2000) illustrating similar physicochemical conditions to those prevailing at Apliki.

\section{Acknowledgements}

The present work has been part of my $\mathrm{PhD}$ dissertation and was partially funded by Papadakis Foundation of the University of Athens under the supervision of Professor N. Skarpelis of the University of Athens whom I sincerely thank for his continuous support and inspiration. I also wish to thank Mr. Konstantinos Xydas, Chief Executive Officer of Hellenic Copper Mines Ltd., for his invaluable help, interest, useful discussions and for permission to use of some of the facilities of the Company, Dr. Nicos Adamides, Senior Geologist for his fieldwork support, his useful discussions and for being a constant source of information and data on the Troodos ophiolite and finally Associate Professor Vas. Tsikouras of the University of Patras, Department of Geology for his thorough comments and suggestions.

\section{References}

Adamides, N.G., 1980. The Form and Environment of Formation of the Kalavasos Ore Deposits, Cyprus. Ophiolites, Proceedings International Ophiolite Symposium, Cyprus 1979, 117-128.

Adamides, N.G., 1982. Geological Report on Apliki. Internal Report, Hellenic Mining Company Ltd., Nicosia, Cyprus.

Adamides, N.G., 1984. Cyprus Volcanogenic Sulphide Deposits in Relation to Their Environment of Formation. Unpublished $\mathrm{PhD}$ Thesis, University of Leicester, 5-20.

Adamides, N.G., 2003a. Geology of Apliki Mine with an Updated Resource Estimate, Internal Report, Hellenic Copper Mines Ltd., Nicosia, Cyprus.

Adamides, N.G., 2010a. MaficDominated Volcanogenic Sulphide Deposits in the Troodos Ophiolite, Cyprus, Part 1-The Deposits of the Solea Graben. Transactions of the 
Institutions of Mining and Metallurgy, Section B: Applied Earth Science, 119, 2, 65-77.

Adamides, N.G., 2014. South Mathiatis: An Unusual Volcanogenic Sulphide Deposit in the Troodos Ophiolite of Cyprus. Transactions of the Institutions of Mining and Metallurgy, Section B: Applied Earth Science, 122, 4, 194206.

Alt, J.C. and Honnorez, J., 1984. Alteration of the Upper Oceanic Crust, DSDP Site 417: Mineralogy and Chemistry, Contributions to Mineralogy \& Petrology, 87, 149-169.

Alt, J.C, Honnorez, J., Laverne, C. \& Emmermann, R., 1986. Hydrothermal Alteration of a $1 \mathrm{~km}$ Section Through the Upper Oceanic Crust, Deep Sea Drilling Project Hole 504B: Mineralogy, Chemistry and Evolution of Seawater-Basalt Interactions, Geophysics Resource, 91, 1030910335.

Alt, J.C., Laverne, C., Vanko, D.A., Tartarotti, P., Teagle, D.A.H., Bach, W., Zuleger, E., Erzinger, J., Honnorez, J., Pezard, P.A., Becker, K., Salisbury, M.H. \& Wilkens, R.H., 1996. Hydrothermal Alteration of a Section of Upper Oceanic Crust in the Eastern Equatorial Pacific: A Synthesis of Results from Site 504 (DSDP Legs 69, 70, and 83, and ODP Legs 111, 137, 140, and 148), In Alt, J.C., Kinoshita, H., Stokking, L.B \& Michael, P.J. (eds), Proceedings of the Ocean Drilling Program, Scientific Results, College Station, TX: Ocean Drilling Program, 417-434.

Alt, J.C., 1999. Hydrothermal alteration and mineralization of ocean crust: Mineralogy, Geochemistry, and Processes, In Barrie, T., Hannington, M. (eds), Volcanic Associated Massive Sulphide, Reviews in Economic Geology, 8, 133-155.
Antivachis, D.N., 2014. Ore deposit geology and environmental impacts from exploitation of the Apliki mine, Skouriotissa mining district, Cyprus. Unpublished Ph.D. Thesis. National and Kapodistrian University of Athens.

A' Shaikh, D., Matsueda, H., Mizuta, T. \& Miyashita, S., 2006. Hydrothermal Alteration of Oman Ophiolite Extrusives in Ghuzay Area, Resource Geology, 56, 2, 167-182.

Barton, P.B., Bethke, P.M. and Roedder, E., 1977. Environment of ore deposition in the Creede mining district, San Juan mountains, Colorado: Part III. Progress toward interpretation of the chemistry of the ore-forming fluid for the $\mathrm{OH}$ vein. Economic Geology, 72, 1-24.

Bear, L.M., 1963. The Mineral Resources and Mining Industry of Cyprus. Cyprus Geological Bulletin, 1.

Bickle, M.J. \& Teagle, D.A.H., 1992. Strontium alteration in the Troodos ophiolite: implications for fluid fluxes and geochemical transport in midocean ridge hydrothermal systems. Earth and Planetary Science Letters, 113, 219-237.

Bruce, J.L., 1947. Cyprus Mines Copper Again, 205-232, Littleton, CO, AIME.

Constantinou, G. \& Govett, G.J.S., 1973. Geology, Geochemistry, and Genesis of Cyprus Sulphide Deposits. Economic Geology, 68, 6, 843-858.

Constantinou, G., 1980. Metallogenesis Associated with the Troodos Ophiolite. In: Panayioutou, A. (Ed), Ophiolites, Proceedings, International Ophiolite Symposium, Cyprus 1979, Cyprus Geological Survey Department, Nicosia, 663-674.

Duhig, N.C., Davidson, G.J. \& Stolz, J., 1992a. Microbial Involvement in the Formation of Cambrian Seafloor Silica Iron Oxide Deposits, Australia. Geology, 20, 511-514. 
Einaudi, M.T., Hedenquist, J.W. \& Inan, E.E., 2003. Sulfidation State of Fluids in Active and Extinct Hydrothermal Systems: Transitions from Porphyry to Epithermal Environments. In Simons S.F. \& Graham, I. (Eds), Society of Economic Geology, Special Publications, 10, 285-313.

Gallahan, W.E. \& Duncan, R.A., 1994. Spatial and Temporal Variability in Crystallization of Celadonites within the Troodos Ophiolite, Cyprus: Implications for Low-Temperature Alteration of the Oceanic Crust. Journal of Geophysical Research, 99, B2, 3147-3161.

Gass, I.G. \& Masson-Smith, D., 1963. The Geology and Gravity Anomalies of the Troodos Massif, Cyprus. In Borradaile, G.J., Lagroix, F., Hamilton, T.D. \& Trebilcock, D.A. (Eds), Ophiolite Tectonics, Rock Magnetism and Paleomagnetism, Cyprus. Surveys in Geophysics, 31, 285-359.

Gillis, K.M. \& Robinson, P.T., 1985. Low-Temperature Alteration of the Extrusive Sequence, Troodos Ophiolite, Cyprus. Canadian Mineralogist, 23, 431-441.

Gillis, K.M. \& Robinson, P.T., 1988. Distribution of Alteration Zones in the Upper Oceanic Crust. Geology, 16, 262-266.

Gillis, K.M. \& Robinson, P.T., 1990. Patterns and Processes of Alteration in the Lavas and Dykes of the Troodos Ophiolite, Cyprus. Journal of Geophysics Research, 95, 2152321548.

Grenne, T. \& Slack, J.F., 2003a. Paleozoic and Mesozoic Silica-Rich Seawater: Evidence from Hematitic Chert (Jasper) Deposits. The Geological Society of America, 31, 4, 319-322.

Hadjistavrinou, Y. \& Constantinou, G., 1982. Cyprus. In Dunning, F.W., Mykura, W. \& Slater, D. (Eds.), Mineral Deposits of Europe, Southeast
Europe. Mineral. Soc., Inst. Min. Metall., 2, 255-277.

Hannington, M.D., Galley, A.G., Herzig, P.M. \& Petersen, S., 1998. Comparison of the TAG Mound and Stockwork Complex with Cyprus-type Massive Sulphide Deposits. Proceedings of the Ocean Drilling Program, Scientific Results, 158, 389-415.

Herzig, P.K., Becker, K.P., Stoffers, P., Backer, H. \& Blum, N., 1988. Hydrothermal Silica Chimney Fields in the Galapagos Spreading Center at $86^{\circ} \mathrm{W}$. Earth Planet Science Letters, 89, 73-86.

Hey, M.H., 1954. A New Review of the Chlorites, Mineralogical Magazine, 30, 277-292, In Kranidiotis \& MacLean (eds), Systematic of Chlorite Alteration at the Phelps Dodge Massive Sulphide Deposit, Matagami, Quebec.

Ixer, R.A., Alabaster, T. \& Pearce, J.A., 1984. Ore Petrography and Geochemistry of Massive Sulphide Deposits within the Semail Ophiolite, Oman. Transactions of the Institutions of Mining and Metallurgy, Section B: Applied Earth Science, 93, B114B124.

Ixer, R.A. Vaughan, D.J., Pattrick, R.A.D. \& Alabasterm T., 1986. Mineralogical Studies and their Bearing on the Genesis of Massive Sulphide Deposits from the Semail Ophiolite complex, Oman, In Gallagher, M.J. et al. (eds) Metallogeny of Basic and Ultrabasic Rocks. Transactions of the Institutions of Mining and Metallurgy: Applied Earth Science, 33-48.

Kelman, M.C., 1999. Hydrothermal Alteration of a Supra-Subduction Zone Ophiolite Analog, Tonga, Southwest Pacific. M.Sc. Thesis, Oregon State University.

Lescuyer, J.L., Oudin, E. \& Beurrier, M., 1988. Review of the Different Types of Mineralization Related to the Oman Ophiolitic Volcanism. Proceedings 7th 
Quadrenniel IAGOD Symposium, E. Schweizerbartsche Verlagsbuchhandl., Stuttgart, 489-500.

Lydon, J.W. \& Galley, A. ,1986. Chemical and Mineralogical Zonation of the Mathiati Alteration Pipe, Cyprus and its Genetic Significance. In Gallagher, M.J., Ixer, R.A., Neary, C.R. \& Prichard, H.M. (Eds) Metallogeny of Basic and Ultrabasic Rocks London, Institution of Mining and Metallurgy, 49-68.

Moores, E. \& Vine, F.J., 1971. The Troodos Massif, Cyprus, and other Ophiolites as Ocean Crust, Evaluation and Implications. In Allerton, S. \& Vine, F.J. (Eds) Spreading Evolution of the Troodos Ophiolite, Cyprus. Geology, 19, 6, 637-640.

Varga, R.J. \& Moores, E.M., 1985. Spreading Structure of the Troodos Ophiolite, Cyprus, Geology, 13, 846850.

Williams, W.C., Meissl, E., Madrid, J. \& De Machuca, B.C., 1999. The San Jorge Porphyry Copper Deposit, Mendoz, Argentina: A Combination of Orthomagmatic and Hydrothermal Mineralization, Ore Geology Reviews, 14, 185-201.

William, X. Chavez Jr., 2000. Supergene Oxidation of Copper Deposits: Zoning and Distribution of Copper Oxide Minerals, SEG Newsletter, 41, 9-21. 